
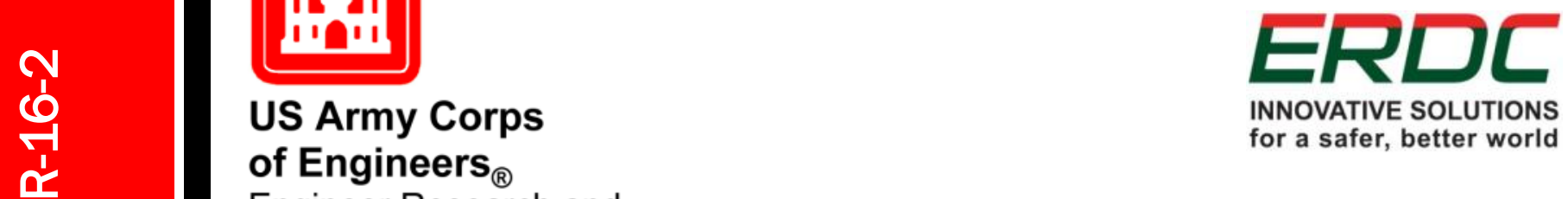
INNOVATIVE SOLUTIONS for a safer, better world

Engineer Research and

Development Center

Wetland Regulatory Assistance Program (WRAP)

\title{
Hydrologic Modeling and Flood Frequency Analysis for Ordinary High Water Mark Delineation
}

John D. Gartner, Mathew K. Mersel, and Robert W. Lichvar

February 2016

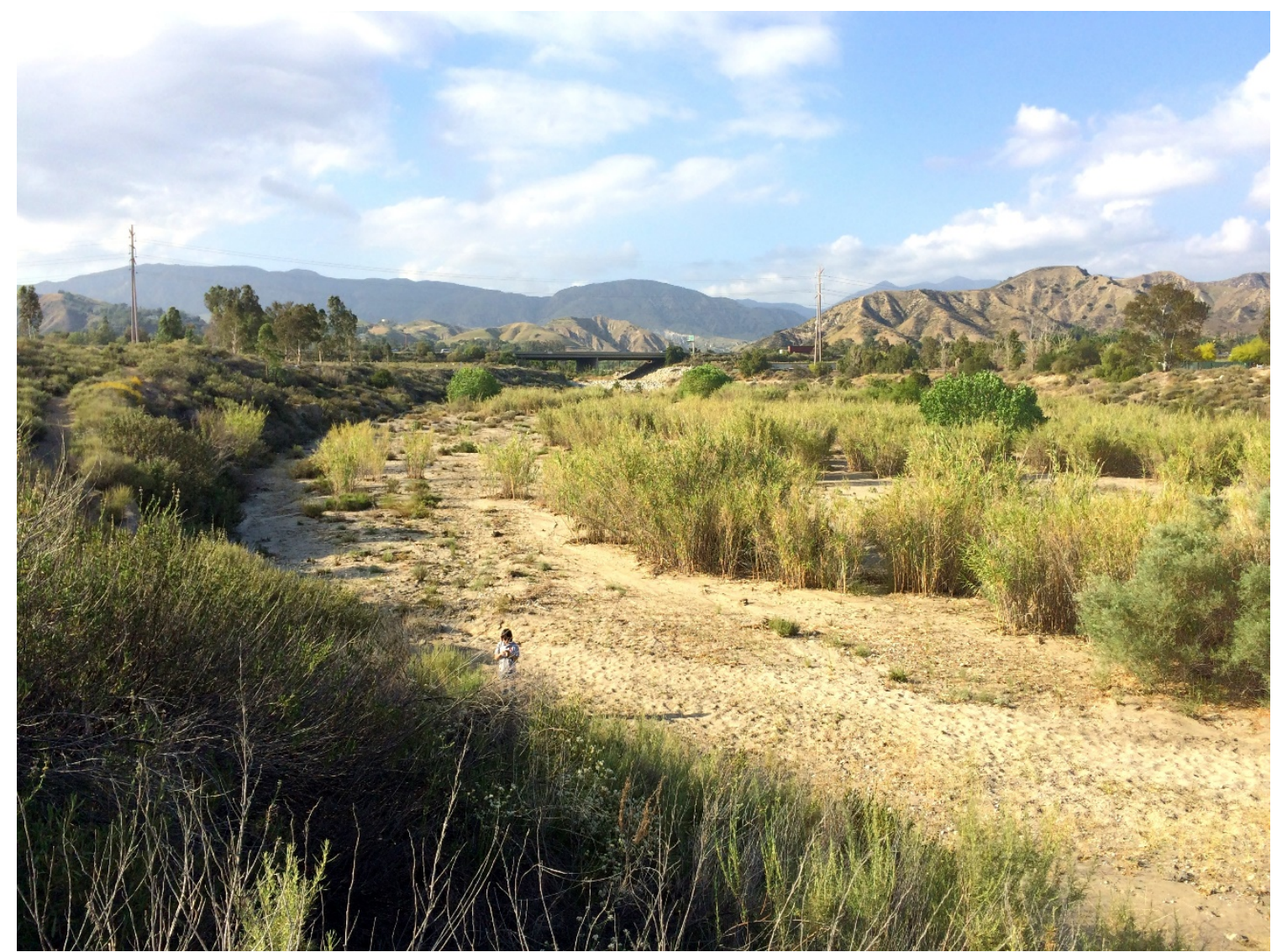


The U.S. Army Engineer Research and Development Center (ERDC) solves the nation's toughest engineering and environmental challenges. ERDC develops innovative solutions in civil and military engineering, geospatial sciences, water resources, and environmental sciences for the Army, the Department of Defense, civilian agencies, and our nation's public good. Find out more at www.erdc.usace.army.mil.

To search for other technical reports published by ERDC, visit the ERDC online library at http://acwc.sdp.sirsi.net/client/default. 


\section{Hydrologic Modeling and Flood Frequency Analysis for Ordinary High Water Mark Delineation}

John D. Gartner, Matthew K. Mersel, and Robert W. Lichvar

U.S. Army Engineer Research and Development Center (ERDC)

Cold Regions Research and Engineering Laboratory (CRREL)

72 Lyme Road

Hanover, NH 03755-1290

Final Report

Approved for public release; distribution is unlimited.

Prepared for Headquarters, U.S. Army Corps of Engineers

Washington, DC 20314-1000

Under Wetlands Regulatory Assistance Program (WRAP) 


\section{Abstract}

This document explores hydrologic modeling and flood frequency analysis for ordinary high water mark (OHWM) delineation performed for Clean Water Act implementation and other applications. OHWM delineation in streams and rivers is primarily based on field indicators, and the streamflow recurrence interval corresponding with the OHWM varies between different sites. However, recurrence intervals are the primary metric that hydrologists use to characterize the variability of streamflow, and recurrence intervals provide context for understanding the OHWM. This document tests modeling techniques for estimating flow frequency and assesses their utility for OHWM delineation. The principal conclusions are that (1) there are multiple ways to estimate streamflow recurrence intervals, each having benefits, limitations, and slightly different results; (2) the uncertainty in flow frequency analysis is one reason why the OHWM typically should not be delineated based on the inundation extent of a specific flow recurrence interval; and (3) despite this uncertainty, quantitative flow frequency analysis can assist in OHWM delineation by helping to eliminate or support potential OHWM locations observed in the field. Two separate companion documents focus on (a) hydraulic modeling for OHWM delineation and (b) the combined use of hydraulic modeling, flow frequency analysis, and field evidence for OHWM delineation.

DISCLAIMER: The contents of this report are not to be used for advertising, publication, or promotional purposes. Citation of trade names does not constitute an official endorsement or approval of the use of such commercial products. All product names and trademarks cited are the property of their respective owners. The findings of this report are not to be construed as an official Department of the Army position unless so designated by other authorized documents. 


\section{Contents}

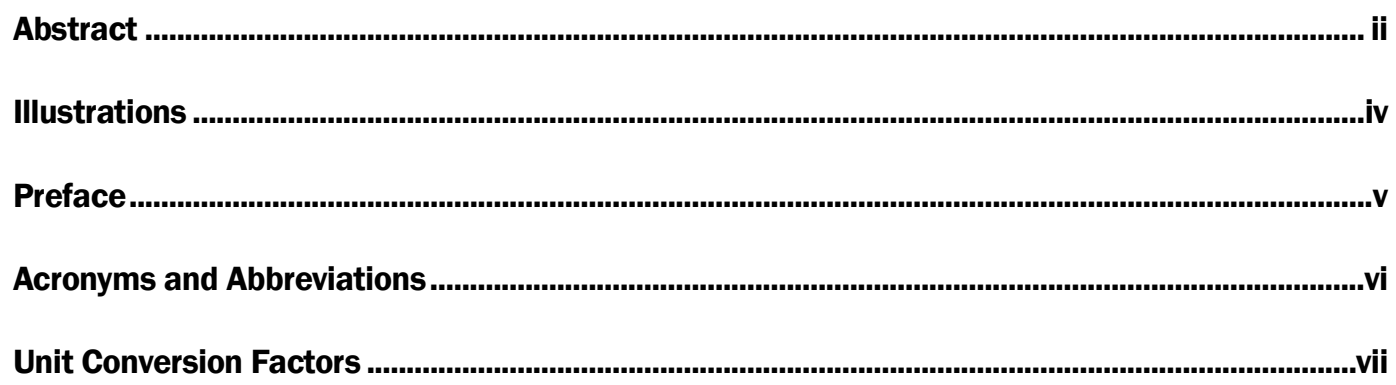

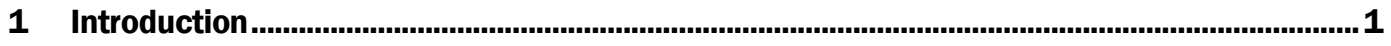

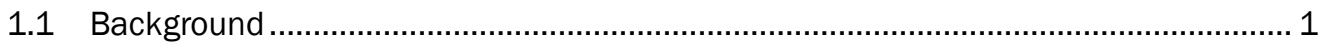

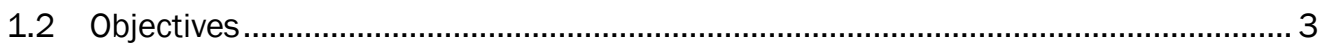

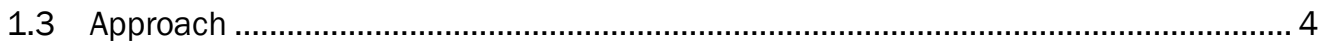

2 Understanding Recurrence Intervals and Flow Frequency Analysis ....................................... 5

2.1 Applications of recurrence intervals ................................................................ 6

2.2 Pertinence to OHWM delineation....................................................................... 7

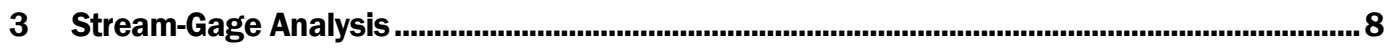

3.1 Gage analysis methods ............................................................................. 10

3.2 Testing and examining gage analysis results .................................................. 12

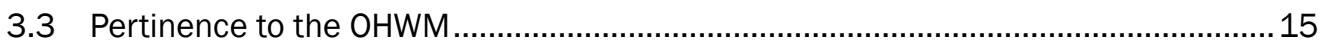

4 Regression Equations ........................................................................................................16

4.1 Advantages, limitations, and examples .......................................................... 16

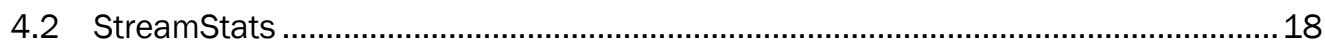

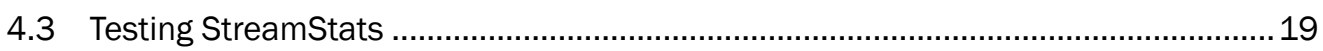

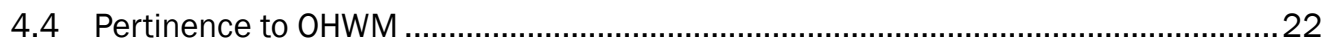

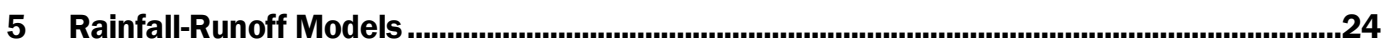

5.1 Rainfall-runoff modeling background .......................................................... 24

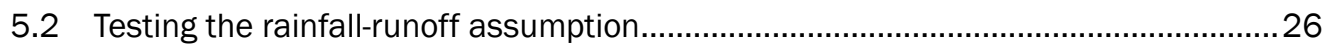

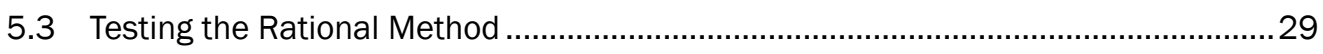

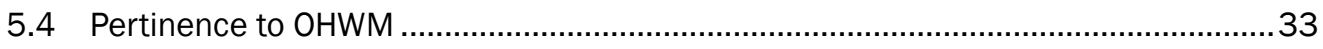

6 Applicability of Modeling Flow Frequency for OHWM Delineation ........................................34

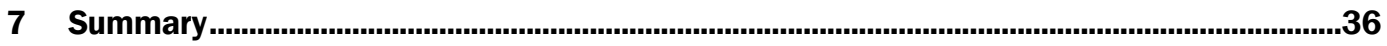

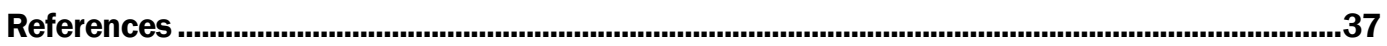

Report Documentation Page 


\section{Illustrations}

\section{Figures}

1 A schematic of an archetypal channel to demonstrate OHWM primary indicators of changes in slope, sediment texture, and vegetation ...........................................................2

2 A Cross-sectional view of Cristianitos Creek, San Clemente, CA, showing flow modeling using the Manning equation (Gartner et al. 2016a) ............................................. 3

3 Gage analysis of Lytle Creek near Fontana, CA, and Ayers Brook near Randolph, VT, showing observed data (dots), Log-Pearson Type III curve (red line), and confidence limits of the curve (green dashed lines)

4 A comparison of long and short records for flow frequency analysis of Lytle Creek

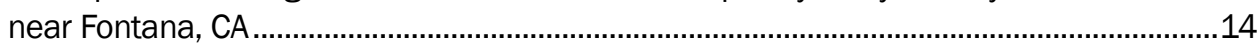

5 Locations of gages used in this study for comparing StreamStats with the gage analysis in arid and humid environments

6 Recurrence intervals of precipitation and peak annual discharge at Mink Brook,

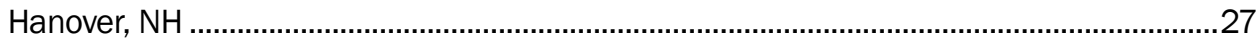

$7 \quad$ Rainfall-runoff relationship at Lytle Creek near Fontana, CA ..............................................28

8 Comparison of the Rational Method with StreamStats and a prorated gage analysis at Sheep Creek near Fontana, CA........................................................................32

9 Different applications of OHWM in modeling: (A) invalid and (B) sometimes appropriate

\section{Tables}

1 A comparison of gage analyses and StreamStats regression equation for Lytle

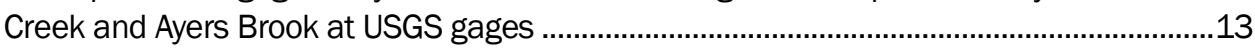

2 Comparison of StreamStats and gage analysis in arid and humid environments..............21

3 Rational Method inputs and results for Sheep Creek subbasin near Fontana, CA.............31 


\section{Preface}

Support and funding for this project were provided by the U.S. Army Corps of Engineers (USACE) Headquarters through the Wetlands Regulatory Assistance Program (WRAP). The authors acknowledge and appreciate the interest and support of Margaret Gaffney-Smith, J ennifer Moyer, Karen Mulligan, and Stacey J ensen of the USACE Headquarters Regulatory Program and Sally Stroupe of the USACE Engineer Research and Development Center (ERDC) Environmental Laboratory.

This report was prepared by J ohn D. Gartner, Matthew K. Mersel, and Robert W. Lichvar (LiDAR and Wetlands Group, David Finnegan, Chief), USACE ERDC Cold Regions Research and Engineering Laboratory (CRREL). At the time of publication, Timothy Pangburn was Director of the Remote Sensing and Geographic Information Systems Center of Expertise (RS/ GIS CX), ERDC-CRREL. The Deputy Director of ERDCCRREL was Dr. Lance Hansen, and the Director was Dr. Robert Davis.

The authors thank J ae Chung and Patrick O'Brian of ERDC-CRREL for their thoughtful and insightful reviews.

COL Bryan S. Green was the Commander of ERDC, and Dr. J effery P. Holland was the Director. 


\section{Acronyms and Abbreviations}

$\begin{array}{ll}\text { CRREL } & \text { U.S. Army Cold Regions Research and Engineering Laboratory } \\ \text { ERDC } & \text { Engineer Research and Development Center } \\ \text { FEMA } & \text { Federal Emergency Management Agency } \\ \text { GIS } & \text { Geographic Information System } \\ \text { HEC-HMS } & \text { Hydraulic Engineering Center Hydrologic Modeling System } \\ \text { HEC-SSP } & \text { Hydraulic Engineering Center Statistics Software Package } \\ \text { IACWD } & \text { Interagency Advisory Committee on Water Data } \\ \text { NSS } & \text { National Streamflow Statistics } \\ \text { OHWM } & \text { Ordinary High Water Mark } \\ \text { SCS } & \text { Soil Conservation Service } \\ \text { USACE } & \text { U.S. Army Corps of Engineers } \\ \text { USGS } & \text { U.S. Geological Survey } \\ \text { WRAP } & \text { Wetland Regulatory Assistance Program } \\ \end{array}$




\section{Unit Conversion Factors}

\begin{tabular}{|l|l|l|}
\hline Multiply & By & To Obtain \\
\hline acres & $4,046.873$ & square meters \\
\hline cubic feet & 0.02831685 & cubic meters \\
\hline feet & 0.3048 & meters \\
\hline inches & 0.0254 & meters \\
\hline miles (U.S. statute) & $1,609.347$ & meters \\
\hline square miles & $2.589998 \mathrm{E}+06$ & square meters \\
\hline
\end{tabular}




\section{Introduction}

\subsection{Background}

Per Section 404 of the Clean Water Act, the ordinary high water mark $(\mathrm{OHWM})$ demarcates the lateral extent of federal jurisdiction in non-tidal waters of the United States, in the absence of adjacent wetlands. The ability to locate the OHWM is important for determining whether certain activities in and near rivers and streams-such as gravel mining; restoring stream banks; building bridges, houses, and roads; and numerous other activities - may need to be reviewed and authorized under the Clean Water Act. Federal regulations define the OHWM as "that line on the shore established by the fluctuations of water and indicated by physical characteristics such as [a] clear, natural line impressed on the bank, shelving, changes in the character of soil, destruction of terrestrial vegetation, the presence of litter and debris, or other appropriate means that consider the characteristics of the surrounding areas" (33 CFR 328.3).*

Building on this definition, a series of manuals and technical reports by the U.S. Army Corps of Engineers (USACE) Engineer Research and Development Center aims to clarify procedures and to reduce some of the difficulties in delineating the OHWM in rivers and streams (e.g., Lichvar et al. 2006; Lichvar and McColley 2008; Curtis et al. 2011; Mersel and Lichvar 2014). These resources focus on the use of field evidence for delineating the OHWM, especially three primary indicators-lateral topographic breaks in slope, changes in vegetation characteristics, and changes in sediment characteristics - as shown in the archetypal channel in Figure 1. Importantly, these documents emphasize that $\mathrm{OHWM}$ delineation is principally a field-based exercise and should not typically be undertaken by hydrologic modeling or recurrence-interval analysis alone.

\footnotetext{
* U.S. Congress. 1986. Definition of "Waters of the United States." Codified at 33 CFR 328.3 (et seq.). Washington, DC: U.S. Government Printing Office.
} 
Figure 1. A schematic of an archetypal channel to demonstrate OHWM primary indicators of changes in slope, sediment texture, and vegetation.

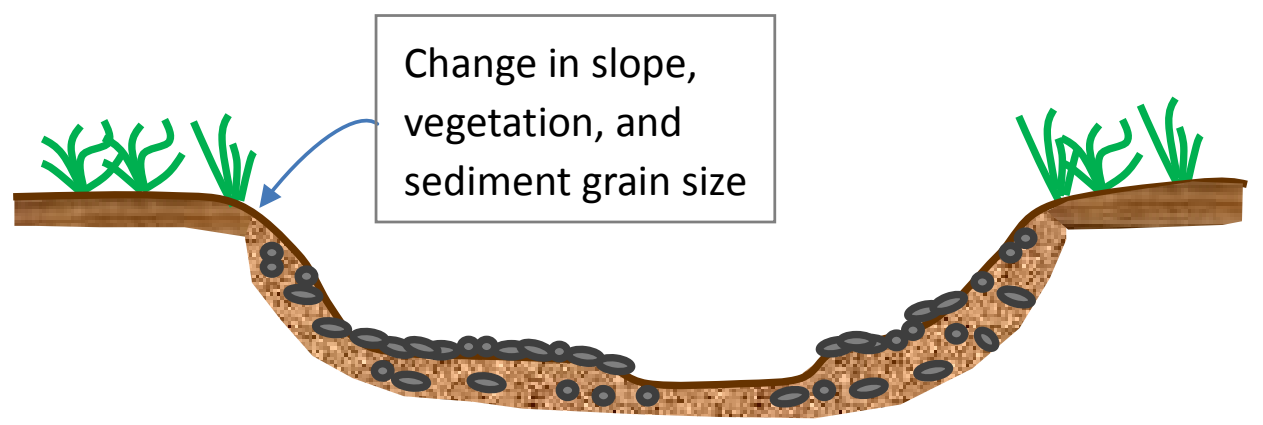

However, in some cases, knowledge of the flow characteristics at a site can assist in OHWM delineation beyond the information provided by field evidence. For example, in some streams, there may be conflicting field indicators or multiple potential OHWM locations based on the available field evidence. This is especially pertinent in arid and semi-arid stream systems, which commonly have one or more low-flow channels within a broader active channel that may have adjacent floodplains and terraces. Each of these geomorphic features may have different characteristic sediment grain sizes, different vegetation characteristics, or a break in slope at its boundaries. It may be difficult to determine which of these locations of change is most reasonably associated with the OHWM, especially for delineators with little experience at a particular site or with OHWM delineation in general.

In challenging delineation situations, knowledge of the streamflow recurrence intervals associated with various field indicators can sometimes be used to rule out or support potential OHWM locations. Figure 2, reproduced from Gartner et al. (2016a), shows estimates of the flow recurrence intervals associated with the elevations of two nested channels (i.e., one is inset within the other) based on field surveys, hydraulic modeling (the Manning equation), and flow frequency analysis (using StreamStats and gage analysis). Field observations indicate that the boundaries of both channels correspond with potential OHWM indicators. However, model results indicate that the smaller channel corresponds with a channel-filling flow that is roughly $1 / 100$ of the 2-year recurrence-interval flow in this location - a flow that is far too small to represent ordinary high water levels. By contrast, the larger channel corresponds with approximately a 5- to 10year flood event, which is consistent with the range of recurrence intervals associated with the OHWM in semi-arid systems (Lichvar et al. 2006; Curtis et al. 2011). Thus, in this scenario, quantitative analysis can effectively 
be used to rule out the field indicators associated with the smaller channel and to provide supporting evidence for the field indicators associated with the larger channel.

Figure 2. A Cross-sectional view of Cristianitos Creek, San Clemente, CA, showing flow modeling using the Manning equation (Gartner et al. 2016a).

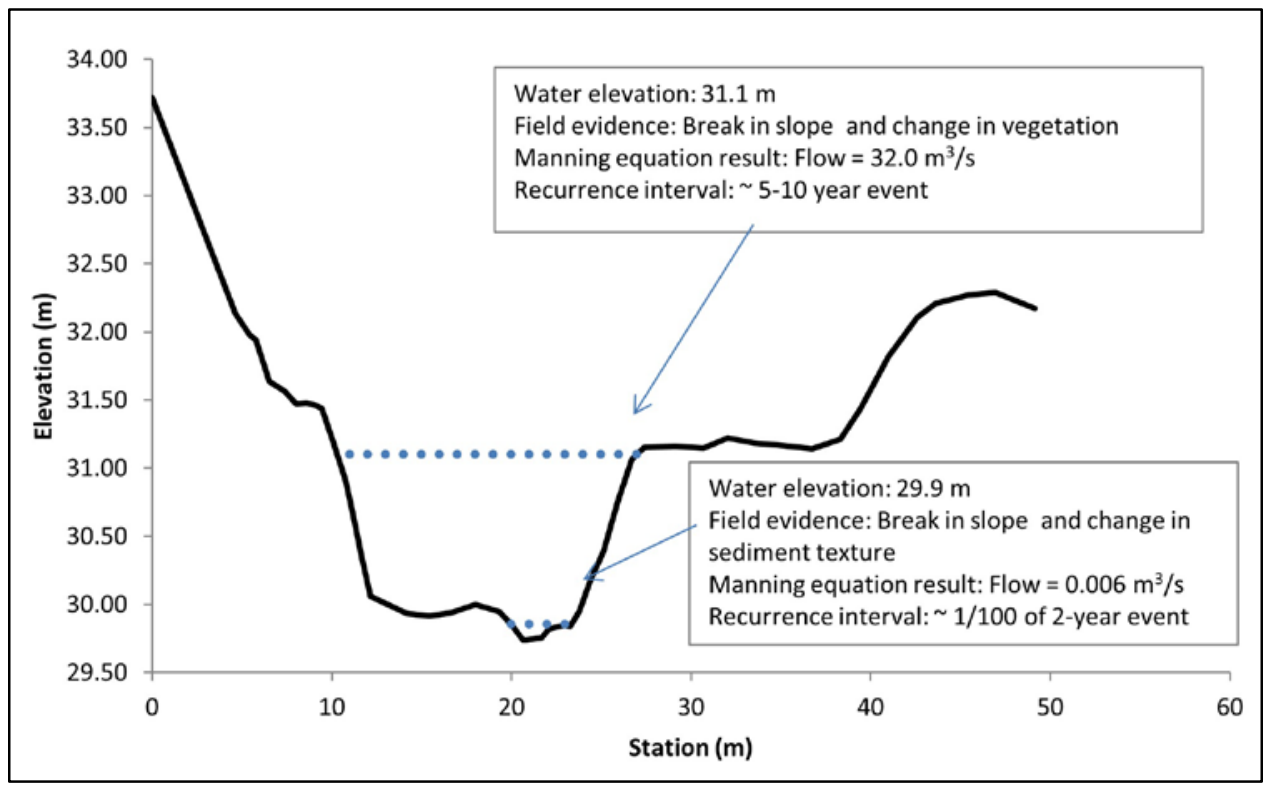

\subsection{Objectives}

There are three principal approaches to flood frequency analysis used to determine the recurrence intervals of peak flows (also known as flood flow frequencies), each with its benefits and limitations: stream-gage analysis, regression equations, and rainfall-runoff modeling. Under a broad view, all three approaches are hydrologic models. They all use a set of inputs (such as a gage record, watershed characteristics, or rainfall intensity) to mathematically compute a desired result, in this case recurrence-interval estimates of particular streamflow amounts.

This report is one of a series of documents exploring the use of modeling in OHWM delineation. Two companion reports focus on (a) hydraulic modeling, which simulates the water surface profile for a given discharge (Gartner et al. 2016a), and (b) case studies to test the combined applicability of hydrologic and hydraulic modeling in OHWM delineation (Gartner et al. 2016b). 
This document is intended for practitioners who are either performing or reviewing OHWM delineations. The aim is to expand the reader's understanding of how modeling is used to determine flow recurrence intervals and how these might be applied or misapplied to OHWM delineations in rivers and streams.

\subsection{Approach}

In this document, Section 2 defines and explores the meaning of recurrence intervals and flood frequency analysis. Section 3 examines and tests how stream-gage data can help to determine and forecast flood flow frequencies. Section 4 focuses on regression equations and investigates how well a composite of gage data from several roughly similar watersheds predicts flow characteristics in ungaged watersheds. Section 5 examines how well rainfall-runoff models use precipitation frequency to estimate flood flow frequency. Section 6 assesses the applicability of these modeling approaches to OHWM delineation. Throughout, this review tests these models to determine which perform best in various situations and how they may or may not be used to support OHWM delineation.

This document does not provide a set of standard procedures to calculate recurrence intervals of flood flows-various technical manuals and tutorials outline those procedures - as that may require specialized training, professional experience, and professional judgment. Instead, this report tests various methods and lists the considerations of the techniques so that regulators and applicants can be better informed about the potential applicability and limitations of hydrologic information for OHWM delineation purposes.

The overarching points of this document are the following:

- There are multiple ways to estimate recurrence intervals. Each technique will give slightly different answers, and each technique has its own benefits and limitations.

- The limited utility of flow frequency analysis for OHWM delineation is due partly to the inherent uncertainty in determining flow recurrence intervals.

- Despite this uncertainty, when performed and applied properly, flow frequency analysis can assist with OHWM delineation in some circumstances. 


\section{Understanding Recurrence Intervals and Flow Frequency Analysis}

The goal of flow frequency analysis is to determine how often flows of various magnitudes occur-for example, the peak flow that occurs, on average, once every 5 years (a.k.a. the 5-year flood). The terms flood flow frequency, flood recurrence interval, and flood return period are essentially synonymous and are defined as the average time interval between actual occurrences of a hydrological event of a given magnitude or greater (IACWD 1982). Flood recurrence intervals are based on the probability that a flood event will be equaled or exceeded in a given year. This probability is determined through statistical techniques, collectively called flow frequency analysis. The relationship between frequency and probability is defined as $T=1 / P$, where $T$ is the recurrence interval and $P$ is the probability of the flood event.

For example, at the U.S. Geological Survey (USGS) stream gage on Lytle Creek near Fontana, CA, the 2-year recurrence-interval flood is estimated to be a flow of approximately $546 \mathrm{ft}^{3} / \mathrm{s}$ based on flow frequency analysis of the stream-gage record. Equivalently, this discharge is estimated to be equaled or exceeded once every 2 years or to have a $50 \%$ probability of occurring in a given year.

It is important to note that the probability of a given event occurring in a given year can differ markedly from the observed frequency of that event over some period of time. For example, a single stream could experience multiple flood events equal to or greater than the 2-year flood in the same year, as occurred in water year 2005 at Lytle Creek. Likewise, 2-year flood events can be separated by 3 or more years, as occurred from 2011 to at least mid-2014 at Lytle Creek. Thus, a given recurrence interval represents only a long-term average frequency of an event.

Recurrence intervals can also be determined for precipitation events. Unlike streamflow recurrence intervals, rainfall recurrence intervals are determined for both the magnitude and the duration of an event. For example, precipitation frequency maps (NOAA 2014) show a 50\% chance that 5.5 in. of rain will fall over a 24-hour period during any given year at the Lytle Creek location. This is called the 2-year, 24-hour storm. There is also 
a $50 \%$ chance that 1.16 in. of rain will fall in this location over a 1-hour period in any given year; and this is called the 2-year, 1-hour storm.

\subsection{Applications of recurrence intervals}

Recurrence intervals are one of the primary ways in which hydrologists, planners, and engineers characterize precipitation and high-flow events. Knowing the frequency at which a flood event is likely to occur provides context for how ordinary or extraordinary a flood event is. Recurrence intervals have also been used to set a common guideline. For example, Federal Emergency Management Agency (FEMA) Flood Zones are established based on areas of the 0.2-percent-annual-chance and 1-percent-annualchance floods, which are equivalent to the 500 - and 100-year flood zone, respectively.

However, there is no universal flood frequency that defines ordinary in the context of the OHWM. Previous studies show that the OHWM correspond with a range of recurrence intervals across different rivers or streams (e.g., Curtis et al. 2011; Mersel and Lichvar 2014). This report demonstrates two principal reasons why no single recurrence interval can be used to characterize or delineate the OHWM. First, there can be substantial uncertainty in determining flow frequencies, as shown in the examples throughout this document. Second, the size and shape of geomorphic features in stream systems (e.g., stream channels, floodplains, etc.) are a function of not only flow history (the basis of flow frequency analysis) but also a range of interrelated processes unique to each system, as demonstrated in greater detail in the following paragraphs.

The 1.5- to 2-year flood has some significance for geomorphologists because it corresponds roughly with the bankfull discharge in many systems (Williams 1978). As Williams and others have shown, there is no consistent way that bankfull stage or discharge is determined, but it is perhaps most commonly defined as the level of the active floodplain or, similarly, as the top of the channel banks where water just begins to spill onto the floodplain. Close inspection of Williams's data shows that only about a third of rivers exhibit bankfull flows near the 1.5- to 2-year flood range, while the full range of bankfull discharges among the sites examined range from 1.01-year to 32-year recurrence-interval floods.

The variability in bankfull discharge recurrence intervals highlights the highly variable relationship between streamflow recurrence intervals and 
geomorphic features observed in the field. The bankfull channel is the cumulative expression of many natural processes, including varying flow levels, sediment inputs from tributaries and hillslopes, erosion and deposition on the bed and banks, and other processes that affect channel form (Knighton 1998). Every river experiences these processes but to varying degrees. Thus, nearly every river has the broadly similar expression of a channel, but the degree to which various processes shape or influence a given channel varies from location to location. Hence, not only does every river have a different flow history but also, more importantly, the history of flows is not the only factor that dictates the channel size.

\subsection{Pertinence to OHWM delineation}

The variable relationship between streamflow and geomorphic features is one of many reasons described in this document why a specific recurrence interval cannot be used to determine the OHWM. At the same time, recurrence intervals can provide some context for the OHWM because they are the principal way that hydrologists and others describe high flows and get a sense of how ordinary or extraordinary a particular flow event is. For example, physical features corresponding with a 100-year flood event can typically be ruled out because a flood that is this infrequent and irregular is well outside of the range of flows reasonably associated with the OHWM. Likewise, features that occur far below the inundation level of a 1year recurrence-interval peak flow can typically be ruled out because flows that recur this frequently are generally below the range of flows associated with the OHWM. Thus, recurrence intervals and the models used to obtain them have pertinence to OHWM delineation, especially in cases where quantifying the extent of extremely low or extremely high flows can help rule out untenable OHWM locations. 


\section{Stream-Gage Analysis}

In essence, stream-gage analysis characterizes past flow events measured at a gage to determine the probability of future events at the location of the gage or at a similar nearby location. Stream-gage analysis is a time-honored method for determining flood flow frequencies. A common approach is to examine the peak annual floods (the highest instantaneous flow that occurs each year) measured at a gage for time periods spanning 10 or more years. This type of data is called a peak annual series. Sometimes partial duration series are analyzed. A partial duration series contains all flows above a certain threshold. The threshold is user defined, and it is often set at the lowest of all the peak annual flows in the period of record. Gage records can also be analyzed to determine the frequency of low flows to characterize droughts. This report focuses on peak annual series because it is the primary method of characterizing high-flow events.

The chief benefit of this technique is that it uses actual measurements of peak stream flows from relatively long stream-gage records. In addition, the results can be scaled to locations along the same stream or even extrapolated to other nearby streams, provided the characteristics of the contributing areas are similar. The drainage-area ratio between the gaged and ungaged sites should be approximately between 0.5 and 1.5. Blakemore et al. (1994) describe this scaling method in detail. This technique also has several limitations, including watershed changes, the paucity of gaging stations, the length of record, the accuracy of peak flow measurements, and other assumptions of statistical procedures.

A major constraint of gage analysis is the scarcity of gaging stations and the dismantling of those with long-term records (Lanfear and Hirsh 1999). It is rare that a site of interest has a nearby gage within the same watershed. Using a gage record to characterize flows at nearby locations can be problematic in areas where the climate, storm patterns, vegetation, and land use can vary greatly from one location to the next, such as in Southern California and in other parts of the Southwest.

Even when a gage is near a site, one must consider possible watershed changes over time because the statistical procedures of standard gage analyses assume stationarity. Many gaged watersheds have flow regulation or urbanization effects that exert a change in the local hydrology. The probability of a given flow event may change over time in response to these 
external sources of hydrologic variability. Therefore, the contributing areas of the gage must be scrutinized for these watershed-scale changes to the hydrologic regime. In addition, climate change may cause systematic changes in the frequency of flood events; climatic trends are notoriously difficult to see in hydrologic records (Milly et al. 2008).

The length of gage record is another primary constraint in stream-gage analysis. Short records may misrepresent the true distribution of stream flows and lead to increased uncertainty in predictions of flood recurrence intervals. Section 3.2 will further assess this concept.

Another concern, although of lesser importance, is the accuracy of peak streamflow measurements. Peak flow data in a stream-gage record can have errors on the order of 5\%-50\%, generally with greater uncertainty in larger floods. Only rarely are the peak annual floods measured directly with flow meters. More commonly, they are estimated indirectly using hydraulic modeling or a rating curve (Rantz 1982; Turnipseed and Sauer 2010). Hydraulic modeling uses surveyed cross-section geometry and high water marks as inputs to one or more mathematical equations to calculate peak discharge, but there are several sources of error in hydraulic models (Gartner et al. 2016a, 2016b). A rating curve relates the stage (the water level elevation above some datum) in the channel to the discharge based on field measurements collected at a variety of flow levels. Unfortunately, high flows often transport sediment and alter channel dimensions over the course of a storm, thereby altering the stage- discharge relationship of the rating curve. With the increasing use of acoustic Doppler current profilers in the last decade, measurements of high flows have become safer, more precise, and more common, improving the accuracy of gaging records of high flows (Hirsch and Costa 2004).

The USGS is one of the leading organizations for stream gaging, setting standards and establishing protocols for high-quality streamflow records. They currently maintain over 7000 stream gages throughout the United States, most of which deliver streamflow data in real time (USGS 2014). The length of gage records ranges from several years to over a century. All of the USGS stream-gage records are available for free online (http://waterdata.usgs.gov/nwis). Typically, hydrologists consider these records accurate enough for flood flow frequency analysis, yet even these records have uncertainty. 
The statistical analysis of flow records assumes that the gaged floods are representative of the floods that occur at the site, which has already been discussed as it relates to length of record, to watershed changes, and to applying a gage record to a nearby area. A second assumption is that annual peak discharges are independent, homogeneous, and random (Blakemore et al. 1994). Regarding homogeneity, mixed populations can occur when there are two different storm types that contribute to peak flows. For example, the frequency of snowmelt flooding may differ from the frequency of monsoon-induced flooding; but both types of flooding events could occur in one watershed, as is commonly seen in mountainous regions of the Southwest. Rather than assess a single frequency that merges these two populations, it may be preferable to undertake the more difficult task of separating these two types of events in the flood record and assessing different frequencies for each. Gage analysis also assumes that the peak flows are a sample of random individual events, such that probability of one event occurring does not depend on the past. For example, a large flood in one year should have no bearing on whether or not a large flood occurs the next year.

\subsection{Gage analysis methods}

Once a gage record of annual peak flows is acquired and determined to reasonably meet these assumptions, there are two common ways to determine recurrence intervals (IACWD 1982). For the first method, the recurrence interval of any given peak flow can be computed by the Weibull Equation, $\mathrm{T}=(\mathrm{n}+1) / \mathrm{m}$, where $\mathrm{T}$ is recurrence interval, $\mathrm{n}$ is the number of years in the record, and $\mathrm{m}$ is the rank of the peak flow of interest. This technique is commonly taught in college classes to introduce the concept of recurrence intervals, and there are several online tutorials (e.g., Baer 2014).

The second method, a Log-Pearson Type III frequency analysis, is slightly more complicated; but it is the standard professional method for computing flood flow frequencies. This method applies a statistical distribution to the peak flow data and computes the associated frequency (i.e., the recurrence interval) for these events. Figure 3 shows how this statistical distribution smooths out the observations and allows extrapolation from the data. 
Figure 3. Gage analysis of Lytle Creek near Fontana, CA, and Ayers Brook near Randolph, VT, showing observed data (dots), Log-Pearson Type III curve (red line), and confidence limits of the curve (green dashed lines).

Bulletin 17B Plot for Lytle Creek nr Fontana, USGS

Return Period

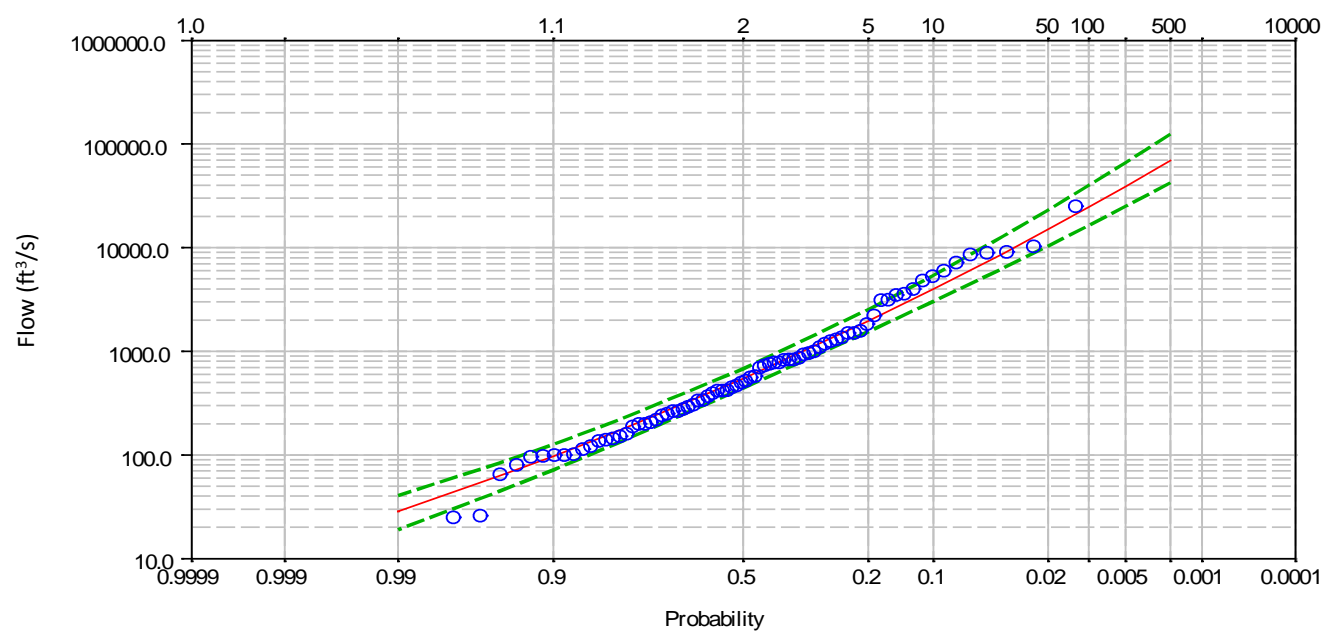

Computed Curve

- - 10 Percent Confidence Limit

---90 Percent Confidence Limit

O Observed Events (Weibull plotting positions)

Bulletin 17B Plot for Ayers Brook, Randolph, VT USGS

Return Period

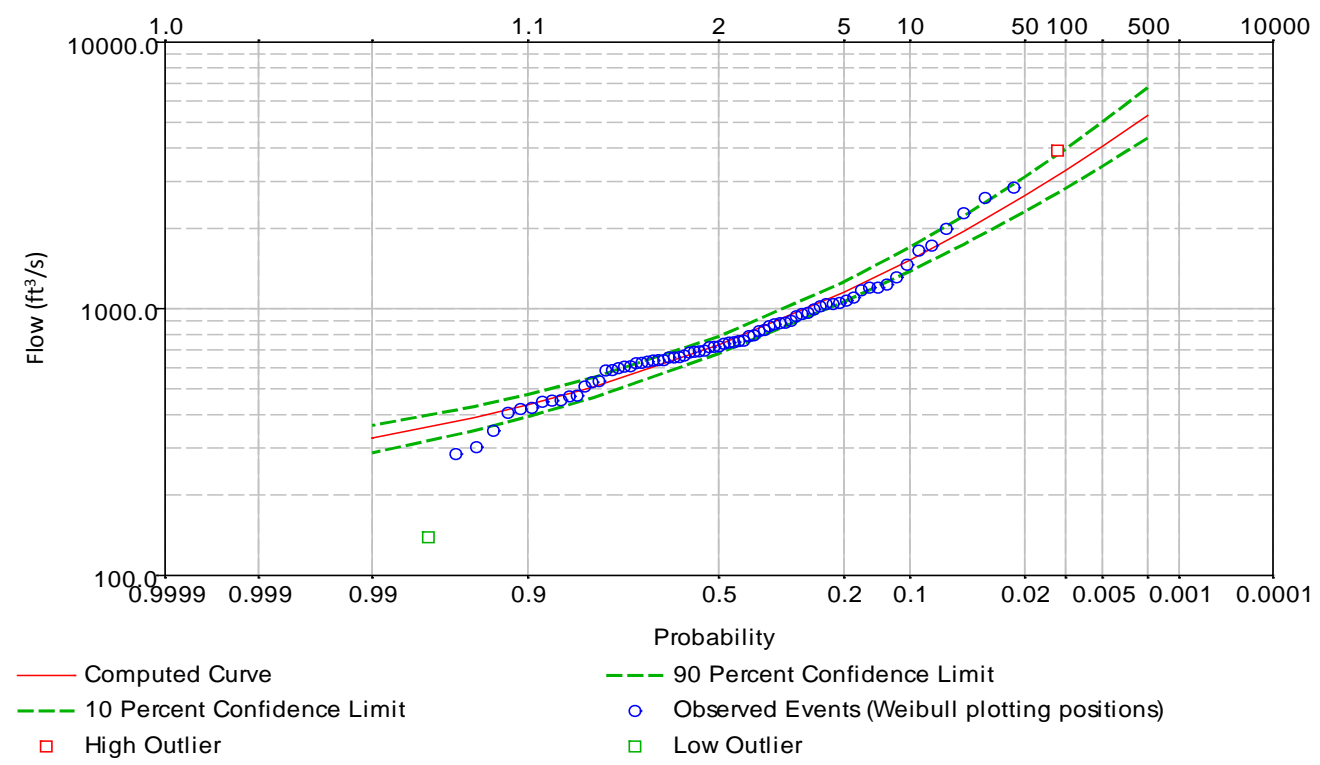

An excellent tool for Log-Pearson Type III and other flood frequency analysis is the Hydraulic Engineering Center Statistics Software Package (HEC-SSP), created by and freely available from USACE (http://www.hec.usace.army.mil/software/hec-ssp/). IACWD (1982) examines in detail the process of Log-Pearson Type III analysis. 
Established protocols to compute confidence limits are a core benefit of a Log-Pearson Type III frequency analysis. Most other types of flow frequency analysis do not have proven means to calculate the standard error or other measures of uncertainty in the result. HEC-SSP allows users to define which confidence limits the program will compute.

\subsection{Testing and examining gage analysis results}

To test the consistency of results between different methods of flow frequency analysis, this study examined Lytle Creek near Fontana, CA (USGS Gage 11062000), and Ayers Brook in Randolph, VT (USGS Gage 01142500), which represent semi-arid and humid environments, respectively. These watersheds are similar in size (47.1 and 30.5 square miles for Lytle and Ayers, respectively). Both watersheds are mostly undeveloped, but there is a small diversion and run-of-river hydroelectric power plant on Lytle Creek about 7 miles upstream of the gage.

Figure 3 shows a HEC-SSP gage analysis of Lytle Creek and Ayers Brook. The blue dots show the observed data based on the Weibull Equation, and the red line shows the Log-Pearson Type III curve (or trend line) fitted to these data. The green lines show the confidence limits. Note the muchgreater variability in observed peak flows in the arid environment of Lytle Creek (about 200-11,000 ft3/s) versus the humid environment of Ayers Brook (about 140- $3900 \mathrm{ft}^{3} / \mathrm{s}$ ).

Table 1 compares selected Lytle Creek and Ayers Brook recurrence intervals computed using the Weibull Equation and a Log-Pearson Type III distribution and results from StreamStats (a regression-based approach to streamflow analysis discussed in the next section). Among these three methods, the computed peak flows are within the same order of magnitude for a given recurrence interval but can differ by up to $25 \%$. The data show clear evidence that the three methods of flow frequency analysis yield similar but not exactly the same results - a theme that this paper continually develops. 
Table 1. A comparison of gage analyses and StreamStats regression equation for Lytle Creek and Ayers Brook at USGS gages.

\begin{tabular}{|c|c|c|c|c|c|c|c|c|}
\hline \multirow{3}{*}{$\begin{array}{l}\text { Flow } \\
\text { Recurrence } \\
\text { Interval }\end{array}$} & \multirow{3}{*}{$\begin{array}{c}\text { Weibull } \\
\text { Distribution }\end{array}$} & \multicolumn{3}{|c|}{$\begin{array}{l}\text { Log-Pearson Type III Using } \\
\text { Entire Record, 1920- } \\
2012\end{array}$} & \multicolumn{3}{|c|}{$\begin{array}{c}\text { Log-Pearson Type III Using } \\
\text { 15-Year Window, } \\
\text { Randomly Selected, } \\
\text { 1938-1959 }\end{array}$} & \multirow{3}{*}{$\begin{array}{l}\text { Stream } \\
\text { Stats }\end{array}$} \\
\hline & & \multirow{2}{*}{$\begin{array}{l}\text { Curve } \\
\text { Value }\end{array}$} & \multicolumn{2}{|c|}{$\begin{array}{l}\text { 90\% Prediction } \\
\text { Interval }\end{array}$} & \multirow{2}{*}{$\begin{array}{l}\text { Curve } \\
\text { Value }\end{array}$} & \multicolumn{2}{|c|}{$\begin{array}{l}\text { 90\% Prediction } \\
\text { Interval }\end{array}$} & \\
\hline & & & Low & High & & Low & High & \\
\hline \multicolumn{9}{|c|}{ Lytle Creek near Fontana, CA, USGS gage 11062000} \\
\hline 2-year & 500 & 546 & 441 & 674 & 478 & 273 & 816 & 805 \\
\hline 5-year & 1830 & 1950 & 1545 & 2527 & 2044 & 1174 & 4159 & 3359 \\
\hline 10-year & 5300 & 3974 & 3033 & 5426 & 4939 & 2604 & 12221 & 7394 \\
\hline 25-year & 9120 & 8798 & 6365 & 12,890 & 13,944 & 6372 & 45,297 & 16,404 \\
\hline \multicolumn{9}{|c|}{ Ayers Brook, Randolph, VT, USGS gage 01142500} \\
\hline 2-year & 731 & 731 & 678 & 787 & 775 & 651 & 919 & 952 \\
\hline 5-year & 1070 & 1152 & 1063 & 1260 & 1206 & 1011 & 1516 & 1410 \\
\hline 10-year & 1555 & 1520 & 1382 & 1698 & 1545 & 1263 & 2051 & 1750 \\
\hline 25-year & 2600 & 2108 & 1873 & 2426 & 2035 & 1604 & 2902 & 2250 \\
\hline
\end{tabular}

Note: All flow values are in units of $\mathrm{ft}^{3} / \mathrm{s}$.

For the gage analysis, the differences between recurrence-interval estimates are distinct enough in magnitude such that the $90 \%$ prediction intervals do not overlap between the displayed recurrence intervals. That is, the potential range of flows for any given recurrence interval (the prediction interval) is mutually exclusive from every other recurrence interval. Prediction intervals indicate the probability that the true flow is within the given bounds of the flow (i.e., the $90 \%$ prediction interval for a flow estimate indicates there is a $90 \%$ chance that the true flow will be between the given flow values) (Ries 2007).

For example, at Lytle Creek, a flow of $1600 \mathrm{ft} 3 / \mathrm{s}$ is within the range of the predicted 5-year flow and is above the range of the predicted 2-year flow, regardless of which type of gage analysis is used. This allows one to conclude with a degree of certainty what the recurrence interval of a given flow could be and, perhaps more important, what it could not be.

On the other hand, these data show that one cannot definitively determine the discharge of a specific recurrence interval, especially in arid systems. At Lytle Creek, the computed $90 \%$ prediction interval of the 10-year flow is between 3033 and $5426 \mathrm{ft}^{3} / \mathrm{s}$, but it could be anywhere within that interval or (less likely) beyond. Among the gaging records in the southwestern 
United States, the Lytle Creek gage provides a relatively narrow $90 \%$ prediction interval because of the long length of record. Even still, the high value is nearly double the low value. In comparison, the range of the $90 \%$ prediction intervals for Ayers Brook is from 1382 to $1698 \mathrm{ft}^{3} / \mathrm{s}$ for the 10year flow, indicating that the lower variability of flood flows in humid regions leads to narrower prediction intervals than in semi-arid regions.

The time period of analysis can also be an important factor in flow frequency analysis, especially for extremely high flows and to a lesser extent for moderate flows. Ten years of record is considered a minimum for flood flow frequency analysis (IACWD 1982); but longer records, on the order of 30 to 50-plus years, are preferable. Long records are more important in arid than in humid areas because of the higher variability in peak flows in arid regions. As the number of long-record stream gages declines in the United States, it is becoming increasingly difficult to find long-term flow records near a site of interest. Fortunately, data from decommissioned USGS gages can still be accessed online.

To test the effect of the length of the gaging record on flood flow frequency results, compare a Log-Pearson Type III analysis of the entire flow record (1920- 2012) for Lytle Creek with a randomly selected 15-year window of the flow record (1938-1959). Table 1 summarizes the results, and Figure 4 shows them graphically.

Figure 4. A comparison of long and short records for flow frequency analysis of Lytle Creek near Fontana, CA.
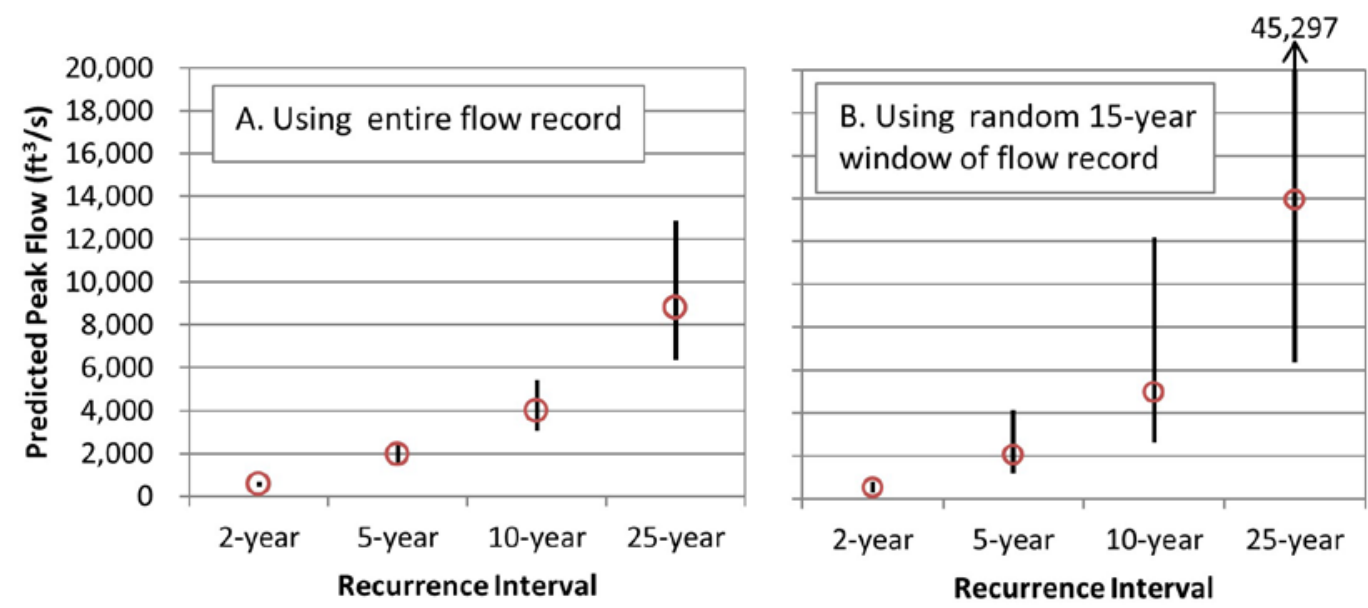

For each time period, the resulting flow values are the same order of magnitude for each recurrence interval. For example, the 10-year flow is approximately $4000 \mathrm{ft}^{3} / \mathrm{s}$ using the entire record and about $5000 \mathrm{ft} 3 / \mathrm{s}$ using 
the randomly-selected 15-year window. However, there is much greater uncertainty when using the 15-year window-so much that there is overlap between the $90 \%$ prediction intervals of the 5-year and 10-year flows and the 10-year and 25-year flows. Large uncertainties arise with the 25-year event because it is inherently difficult to extrapolate a 25-year flow event from 15 years of recorded flow.

These data show the great importance of long records in high-variability systems compared to lower-variability systems (Table 1). For example, the 10-year recurrence-interval flow using 15 years of record has a $90 \%$ confidence interval of about 1250-2050 $\mathrm{ft}^{3} / \mathrm{s}$ at Ayers Brook. At Lytle Creek, this span is about $2600-12,200 \mathrm{ft}^{3} / \mathrm{s}$, an order of magnitude difference. This greater uncertainty is due in part to the episodic nature of El Niño and La Niña cycles and to the generally higher variability in flows in drier regions.

\subsection{Pertinence to the OHWM}

In sum, these data show that even when directly measured in situ, streamflow data are subject to substantial uncertainty, thus limiting the utility of hydrologic data for OHWM delineation purposes. This variability emphasizes why one cannot simply pick a recurrence interval, model the width of that flow in a channel, and call this result the OHWM. Even if it were possible to name a specific recurrence interval to represent the OHWM, it would not be possible to determine the exact corresponding flow value. There is substantial uncertainty inherent in gage analysis and in all other types of flow frequency analysis.

However, even order-of-magnitude accuracy in flow frequency analyses of gage records may help to narrow down the OHWM location or to rule out potential OHWM locations in certain circumstances, as Section 6 discusses in greater detail. Apart from determining recurrence intervals, gage analysis in the region of a site of interest can give a sense of the timing of flooding events at the site. This historical information can also help with interpreting the physical conditions at a site. 


\section{Regression Equations}

Regional regression analysis compiles gage records from multiple watersheds to determine the physiographic characteristics (e.g., watershed size, precipitation, and land cover) that best predict the magnitudes of various recurrence intervals of peak flows. The watershed and climatic characteristics are predictor variables of flood return periods. The derived regression equations can then be used to predict streamflow recurrence intervals at similar locations, gaged or ungaged.

\subsection{Advantages, limitations, and examples}

Because they use many data points (i.e., multiple years of flood events from multiple locations), regression equations may reduce the errors and uncertainties of a single gage record (Kirby and Moss 1987). These equations may outperform standard gage-record analysis even at the site of a gage - a situation more likely in the Southwest region where flood flow variability is high and gage records may be short (Blakemore et al. 1994). At gaged sites, the best estimates of flood frequency are weighted estimates, which combine gage data with regression equation results, described in detail in Blakemore et al. (1994, 13).

The main limitations of regression equations are the following:

- They rely on the assumption that the location of interest has similar watershed characteristics as the gages that were used to determine the regression equations - an assumption that can be violated in the case of flow regulation or urbanization.

- Not all areas of the United States have well-established and verified regression equations.

- The uncertainties from gage analyses are partially transferred by the regression equations to the recurrence-interval estimates.

As part of the National Streamflow Statistics (NSS) program, the USGS has developed and published regional regression equations for every state in the United States, for the Commonwealth of Puerto Rico, and for many U.S. metropolitan areas (Ries 2007). The regression equations often take this form:

$$
Q_{x}=a X^{b} Y^{c} Z^{d},
$$


where $\mathrm{Q}_{\mathrm{x}}$ represents the $\mathrm{x}$-year flood flow (the dependent variable); $\mathrm{X}, \mathrm{Y}$, and $Z$ are watershed or climatic characteristics used as independent variables; and a, b, c, and d are regression coefficients. The number of characteristics in the equations varies from region to region. Likewise, the values of the regression coefficients vary between regions. Commonly, the NSS program has developed separate equations for rural and urban areas.

For example, one equation from Blakemore et al. (1994), derived for the eastern Sierra (Region 5 of the Southwest), states that the 5-year recurrence-interval discharge is a function of the drainage area, elevation, and latitude of the contributing watershed:

$$
\left.\mathrm{Q}_{5}=2.42(\mathrm{AREA})^{0.823}(\mathrm{ELEV} / 1,000)^{1.01}[(\mathrm{LAT}-28) / 10)\right]^{4.1} \text {. }
$$

Another example, derived for northeastern Arizona, states that 5-year recurrence-interval discharge is a function of the drainage area and evaporation:

$$
Q_{5}=0.10(A R E A)^{0.52} E V A P^{2.0} .
$$

As evident in the above examples, these empirical equations do not fully reflect underlying physical processes. Note that the units are not consistent from one side of the equation to the other. These equations simply reflect that drainage area and other independent variables are good predictors of the magnitude of the 5-year flood in a given region. Drainage area is typically one of the independent variables; but the exponents, correction factors, and other variables, if any, are site specific and geographically limited. Other variables may be significant only as proxies of other characteristics; for example, elevation and latitude are indices of the type and amount of precipitation. Clearly, a regression equation for Vermont would not work in southern California. Moreover, a regression equation for a location in southern California may be applicable if the watershed were rural but might not be justifiable if the watershed were even $5 \%$ urbanized. Nationwide regression equations for urban areas have been developed by Sauer et al. (1983) and reviewed by Gotvald et al. (2012).

It is important to note that while regression equations are useful for estimating streamflow recurrence intervals, especially at ungaged locations, they do not indicate the actual history at a site. For instance, a regression 
equation can provide an informed estimate of the 5-year flood, but it cannot provide the location, timing, or magnitude of the last 5-year flood event as can a stream gage. A gage or set of gages near the location of interest might elucidate the recent history of high flows. Often the gage records near a site of interest can provide rudimentary information on the last wet and dry periods and likely times of very high-flow events even if the regression equations provide a more robust estimate of the flood recurrence intervals. Hence, stream gages and regression equations are complementary tools for streamflow analysis.

\subsection{StreamStats}

Over the last decade, the USGS has created and augmented StreamStats, which makes recurrence intervals computed by regional regression equations from NSS easily accessible throughout much of the United States (Ries et al. 2008). This online, GIS- (geographic information system) enabled program allows users to pinpoint a location of interest. On request, the program will automatically extract geographic information, access a regression equation for that location, and produce a site-specific table of recurrence intervals. Other data are easily extracted from the StreamStats program, such as the drainage area, a GIS shapefile of the watershed, and an elevation profile along a flow path. These data can be useful when examining the conditions upstream of a point of interest and when determining if StreamStats is applicable to the site. StreamStats is unavailable in some states because of funding constraints-implementation requires cooperative funding between the USGS and one or more federal, state, or local agencies. The web interface is located at http://water.usgs.gov/osw/streamstats/. The program is optimized for use with Microsoft Internet Explorer versions 5 and above; it does not perform as well with other browsers such as Mozilla or Google Chrome.

The ease of use of the StreamStats program makes it an efficient tool for flow frequency analysis, but the applicability and limitations must be understood to use it effectively. Each state with StreamStats has a publication that documents the regression equations and how they were derived. Typically, the gages, which are the foundation of the regression equations, are in moderate-sized watersheds with minimal disturbances from flow regulation, urbanization, and other impacts. Thus, the StreamStats program works best for locations in similar moderate-sized watersheds with minimal development and without flow-regulating dams or large diversions. Sometimes StreamStats can be used in impacted watersheds to estimate 
what the natural flow recurrence intervals would have been in the absence of the impacts. However, in all watersheds, whether impacted or not, OHWM delineations should be based on current landscape and streamflow conditions at a given site, even if existing impacts make the flood flows higher or lower than they would have been otherwise.

StreamStats users must be careful to understand the conditions in the area of the point of interest. This can be time-consuming as there is no single location that lists all the impacts for every watershed in the United States. Aerial imagery analysis can offer an initial glimpse of watershed conditions, but many impacts may be difficult to observe. In a way, the ease of StreamStats presents a problem. The flow recurrence intervals are so easily and quickly obtained that users may be tempted to skip the due diligence required to understand the watershed conditions upstream of the point of interest and to determine how applicable the StreamStats regression equations are to the site.

StreamStats does not automatically generate all of the equations or information in the NSS program. Most important for OHWM delineation, StreamStats does not access the urban area regression equations and sometimes does not use the most up-to-date rural regression equations because of funding issues. Even if StreamStats does not use the appropriate regression equation, users can still access the drainage area, elevation, and other physiographic information that is automatically obtained and reported in StreamStats. These parameters can be input into the appropriate regression equations from the NSS program, if available. This procedure requires more user effort, but the results will be more defensible than using simply the automated recurrence-interval results.

In addition, StreamStats often does not compute the prediction confidence intervals; and, as demonstrated throughout this document, the uncertainty of recurrence-interval predications is a core issue in their use for OHWM. For some states, the StreamStats documentation shows equations for computing the prediction confidence intervals, even if the prediction confidence intervals are not generated automatically in the StreamStats program.

\subsection{Testing StreamStats}

This section tests how well StreamStats compares with gage analysis at nine sites representing the dry southwestern United States and the wet 
northeastern United States. Most of these nine gages are deemed "reference" gages by the USGS in the GAGES II program, which has selected stream gages with long records across the United States in some of the least-disturbed watersheds in their respective regions. Table 2 summarizes the site names, USGS gage numbers, and lengths of gage records in years. Figure 5 shows the stream-gage locations. For the gage analysis, this study computed peak annual flood recurrence intervals by using Log-Pearson Type III distribution in HEC-SSP. For StreamStats results, the table reports the $90 \%$ confidence limits for only the Northeast gages because the StreamStats website does not report confidence limits for the drier, highly variable locations. The regression estimates for California were derived by first obtaining the watershed characteristics from the StreamStats program and then entering these values into updated regression equations (Gotvald et al. 2012).

Figure 5. Locations of gages used in this study for comparing StreamStats with the gage analysis in arid and humid environments.

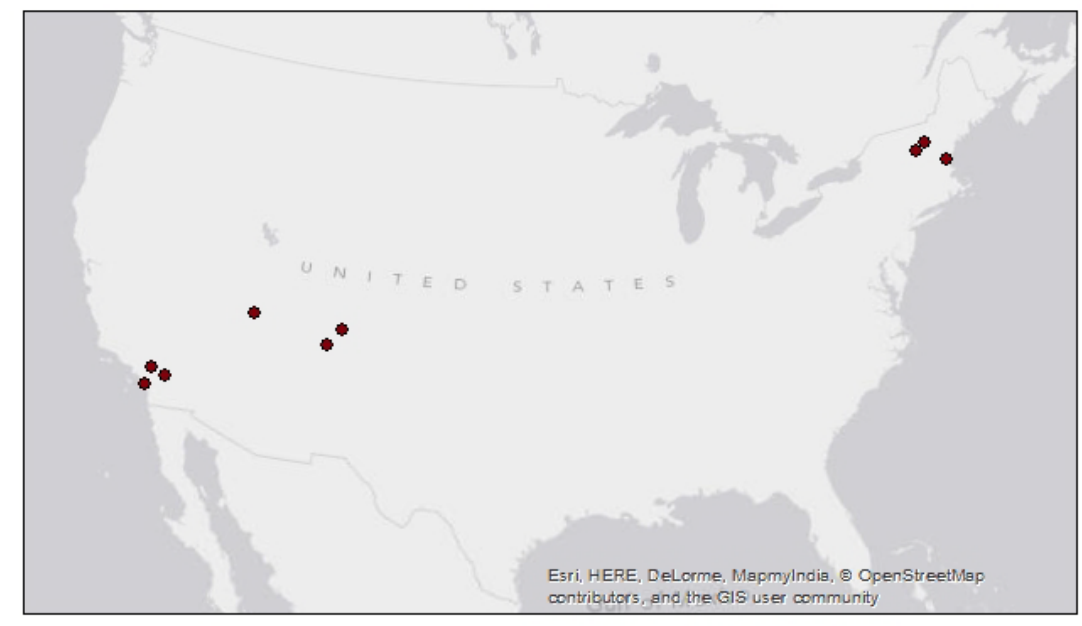

Table 2 compares the StreamStats results with the gage analysis results. It is difficult to determine which method produces more accurate results as the true recurrence intervals are not known. Given these data, the best approach at any single site may be to combine the gage analysis with the regression equation results as described in Gotvald et al. (2012) and Blakemore et al. (1994). However, here, the results are separate to compare methods. 
Table 2. Comparison of StreamStats and gage analysis in arid and humid environments.

\begin{tabular}{|c|c|c|c|c|c|c|c|c|c|c|}
\hline \multirow[b]{3}{*}{ Location } & \multirow{3}{*}{$\begin{array}{l}\text { USGS } \\
\text { Gage } \\
\text { Number }\end{array}$} & \multirow{3}{*}{$\begin{array}{l}\text { Years of } \\
\text { Record }\end{array}$} & \multirow{3}{*}{$\begin{array}{c}\text { Recurrence } \\
\text { Interval }\end{array}$} & \multicolumn{3}{|c|}{ Log-Pearson Type III } & \multicolumn{3}{|c|}{ StreamStats } & \multirow{3}{*}{$\begin{array}{c}\text { StreamStats } \\
\text { within Gage } \\
90 \% ?\end{array}$} \\
\hline & & & & \multirow{2}{*}{$\begin{array}{l}\text { Predicted } \\
\text { flow }\end{array}$} & \multicolumn{2}{|c|}{$\begin{array}{c}90 \% \text { Confidence } \\
\text { Limit }\end{array}$} & \multirow{2}{*}{$\begin{array}{c}\text { Predicted } \\
\text { flow }\end{array}$} & \multicolumn{2}{|c|}{$\begin{array}{c}90 \% \text { Confidence } \\
\text { Limit }\end{array}$} & \\
\hline & & & & & Low & High & & Low & High & \\
\hline \multirow{6}{*}{$\begin{array}{l}\text { Cristianitos Creek } \\
\text { above San Mateo } \\
\text { Creek near San } \\
\text { Clemente, CA }\end{array}$} & \multirow[t]{6}{*}{11046360} & \multirow[t]{6}{*}{21} & 2-year & 218 & 125 & 381 & 309 & & & yes \\
\hline & & & 5-year & 1133 & 630 & 2345 & 1124 & & & yes \\
\hline & & & 10-year & 2692 & 1389 & 6469 & 2020 & & & yes \\
\hline & & & 25-year & 6794 & 3152 & 19,649 & 3480 & & & yes \\
\hline & & & 50-year & 12,374 & 5312 & 40,716 & 4840 & & & no \\
\hline & & & 100-year & 21,242 & 8467 & 78,840 & 6368 & & & no \\
\hline \multirow{6}{*}{$\begin{array}{l}\text { Lytle Creek near } \\
\text { Fontana, CA }\end{array}$} & 11062000 & 78 & 2-year & 546 & 441 & 674 & 805 & & & no \\
\hline & & & 5-year & 1950 & 1545 & 2527 & 3359 & & & no \\
\hline & & & 10-year & 3974 & 3033 & 5426 & 7394 & & & no \\
\hline & & & 25-year & 8798 & 6365 & 12,890 & 16,404 & & & no \\
\hline & & & 50-year & 14,996 & 10,422 & 23,134 & 26,582 & & & no \\
\hline & & & 100-year & 24,552 & 16,409 & 39,809 & 39,548 & & & yes \\
\hline Mission Creek & 10257600 & 44 & 2-year & 29 & 18 & 45 & 90 & & & no \\
\hline near Desert Hot & & & 5-year & 204 & 125 & 357 & 457 & & & no \\
\hline Springs, CA & & & 10-year & 565 & 325 & 1101 & 1074 & & & yes \\
\hline & & & 25-year & 1673 & 879 & 3720 & 2679 & & & yes \\
\hline & & & 50-year & 3372 & 1658 & 8221 & 9524 & & & no \\
\hline & & & 100-year & 6331 & 2926 & 16,818 & 24,933 & & & no \\
\hline Mammoth Creek & 10173450 & 49 & 2-year & 413 & 377 & 452 & 345 & & & no \\
\hline above West Hatch & & & 5-year & 618 & 560 & 692 & 828 & & & no \\
\hline Ditch near Hatch, & & & 10-year & 758 & 678 & 866 & 1290 & & & no \\
\hline UT & & & 25-year & 938 & 825 & 1098 & 2050 & & & no \\
\hline & & & 50-year & 1074 & 934 & 1278 & 2740 & & & no \\
\hline & & & 100-year & 1211 & 1041 & 1464 & 3560 & & & no \\
\hline La Plata River & 09367500 & 52 & 2-year & 873 & 728 & 1050 & 1470 & & & no \\
\hline near Farmington, & & & 5-year & 2030 & 1660 & 2549 & 2350 & & & yes \\
\hline NM & & & 10-year & 2998 & 2398 & 3892 & 3380 & & & yes \\
\hline & & & 25-year & 4381 & 3413 & 5902 & 5150 & & & yes \\
\hline & & & 50-year & 5490 & 4202 & 7575 & 6630 & & & yes \\
\hline & & & 100-year & 6641 & 5005 & 9356 & 8550 & & & yes \\
\hline Vallecito Creek & 09352900 & 51 & 2-year & 1126 & 1041 & 1214 & 458 & & & no \\
\hline near Bayfield, CO & & & 5-year & 1662 & 1535 & 1818 & 800 & & & no \\
\hline & & & 10-year & 2175 & 1976 & 2438 & 1080 & & & no \\
\hline & & & 25-year & 3054 & 2696 & 3563 & 1530 & & & no \\
\hline & & & 50-year & 3918 & 3378 & 4723 & 1850 & & & no \\
\hline & & & 100-year & 5006 & 4209 & 6237 & 2200 & & & no \\
\hline Ayers Brook, & & 75 & 2-year & 731 & 678 & 787 & 952 & 498 & 1820 & no \\
\hline Randolph, VT & & & 5-year & 1152 & 1063 & 1260 & 1410 & 748 & 2670 & no \\
\hline & & & 10-year & 1520 & 1382 & 1698 & 1750 & 921 & 3340 & no \\
\hline & & & 25-year & 2108 & 1873 & 2426 & 2250 & 1180 & 4320 & yes \\
\hline & & & 50-year & 2650 & 2312 & 3121 & 2260 & 1370 & 5160 & no \\
\hline & & & 100-year & 3295 & 2823 & 3971 & 3080 & 1550 & 6130 & yes \\
\hline Ammonoosuc & & 45 & 2-year & 10,581 & 9699 & 11,529 & 8720 & 5350 & 14,200 & no \\
\hline River, Bath, NH & & & 5-year & 15,716 & 14,317 & 17,492 & 12,200 & 7420 & 20,200 & no \\
\hline & & & 10-year & 19,676 & 17,663 & 22,415 & 15,000 & 8910 & 25,100 & no \\
\hline & & & 25-year & 25,355 & 22,271 & 29,806 & 18,300 & 10,500 & 31,800 & no \\
\hline & & & 50-year & 30,101 & 26,006 & 36,213 & 20,900 & 11,700 & 37,400 & no \\
\hline & & & 100-year & 35,311 & 30,013 & 43,441 & 24,000 & 13,000 & 44,400 & no \\
\hline Oyster River, & & 79 & 2-year & 304 & 281 & 329 & 257 & 158 & 418 & no \\
\hline Durham, NH & & & 5-year & 487 & 447 & 536 & 420 & 254 & 692 & no \\
\hline & & & 10-year & 630 & 570 & 707 & 555 & 330 & 933 & no \\
\hline & & & 25-year & 837 & 743 & 962 & 737 & 424 & 1280 & no \\
\hline & & & 50-year & 1010 & 885 & 1183 & 887 & 496 & 1590 & yes \\
\hline & & & 100-year & 1201 & 1037 & 1430 & 1070 & 578 & 1980 & yes \\
\hline
\end{tabular}


The same themes established in the section on gage analysis hold true in this comparison. First, computed recurrence intervals should be considered rough estimates. Different methods often produce results that are significantly different but that are typically within the same order of magnitude. In this comparison, the StreamStats estimates are outside of the $90 \%$ confidence intervals of the gage analysis in about a third of the estimates. However, StreamStats results have a broader prediction interval, indicating greater uncertainty. As a result, the gage analysis estimates are within the $90 \%$ confidence limits of StreamStats in all of the cases where the confidence intervals are available.

The second theme, consistent with gage analysis, is that the moderate flows are typically significantly lower than the extreme flows. At all sites, the 2- to 10-year recurrence-interval floods are significantly lower than the 50- to 100-year floods. In other words, the maximum value for the 10-year flood is lower than the minimum value of the 50-year flood. Even in arid landscapes where the highly variable flows increase uncertainty in flow frequency analysis, this difference between moderate and extreme flood events is apparent.

In sum, StreamStats is an excellent resource for hydrologists and others interested in flood recurrence intervals.

\subsection{Pertinence to OHWM}

Regression equations, because of their defensible recurrence-interval estimates combined with their ease of use, especially through the StreamStats program, are an efficient tool for flow frequency analysis for OHWM purposes. Although the equations can be easy to use, one must take great care to verify that the regression equations are applicable to the site at hand. This method is best suited for watersheds that have characteristics within the range of characteristics of the watersheds from which the regression equations were derived. Typically, the equations used in StreamStats are derived from moderate-sized watershed without urbanization, flow regulation, or flow diversions. In sites with these impacts, the basin characteristics derived from StreamStats can be input into suitable regression equations, especially for urbanized watersheds (Sauer et al. 1983), or used as some of the inputs into rainfall-runoff models. The following are the primary limitations to the StreamStats regression equations: 
- They are region-specific.

- They predict flow frequencies for only undisturbed watersheds.

- Being empirical relations, they cannot be easily adjusted to account for physical changes in the watershed.

In altered watersheds, regression equations give a sense of flood recurrence intervals prior to the impacts. However, OHWM delineations should be based on current landscape and streamflow conditions at a given site (Lichvar and McColley 2008; Mersel and Lichvar 2014), even if existing impacts make the flood flows higher or lower than they would be otherwise. 


\section{Rainfall-Runoff Models}

Whereas gage analysis and regression models are limited to a specific site or region, rainfall-runoff hydrologic models can be applied to essentially any location, regardless of watershed size or conditions. These models simulate the amount of runoff (a term that is equivalent to discharge or flow) for a single rainfall event or continuously for a series of rain events. This section examines and tests how rainfall-runoff models can help to determine flood flow frequencies and begins by defining the different types of rainfall-runoff models. Next, it assesses the basic assumptions of the rainfall-runoff relationship and finishes by testing the Rational Method, one of the most commonly used hydrologic models for small watersheds. Through this section, it becomes evident that there are some situations where flow recurrence intervals derived from hydrologic modeling could assist in OHWM delineation; but usually the effort and uncertainty associated with these flow recurrence estimates outweigh the benefits for OHWM delineation. Typically, regression equations and, to a lesser extent, gage analysis are preferred options to determine flow recurrence intervals for OHWM purposes.

\subsection{Rainfall-runoff modeling background}

As described in the introduction, models take known or estimated inputs and relate them to unknown outputs. In the case of rainfall-runoff models, the typical inputs are precipitation and basin characteristics, such as rainfall intensity, drainage area, and infiltration rates. The outputs are often peak discharge (in units of flow volume per time) or a flow hydrograph, which shows discharge over time.

In the context of rainfall-runoff modeling, the there is a distinction between small, midsize, and large watersheds, and the terms small, midsize, and large are based on the variations in the dominant processes that should be modeled (Ponce 1989). In small watersheds, runoff travels primarily by overland flow and spends a relatively short period of time as flow within the stream channel. In midsize watersheds, runoff travels more equivalently as overland flow and channel flow. In large watersheds, most of the runoff travel time is spent in the channel. It can take several hours or days for water to travel from the headwaters to the basin outlet and to fill all the backwater areas along the way. In these large watersheds, the routing and storage of water in the channel must be modeled carefully, 
while in small watersheds, these channel processes are often not modeled explicitly. In small watersheds, rainfall intensity does not change over the duration of a storm because the time of concentration (which is the time required to achieve peak flow) is short relative to the storm duration. In midsize and large watersheds, however, rainfall intensity can change over the duration of the storm because it takes longer to reach the peak flow.

Different models are better suited for different watershed sizes (Ponce 1989; Maidment 1993; Rawls et al. 1996). For small watersheds (under 200 acres), the Rational Method is typically the model of choice. For midsize watersheds, the Soil Conservation Service (SCS) runoff curve number method combined with the Unit Hydrograph approach is widely used. For large watersheds, the Hydrologic Engineering Center Hydrologic Modeling System (HEC-HMS) model by USACE is widely used. HEC-HMS incorporates channel routing models that simulate the varying times it takes for water to move through a network of channels (Scharffenberg 2013). As watersheds get larger, the routing of water becomes more important.

There are two primary ways to use rainfall-runoff models to estimate flood flow frequencies (Feldman 1979). One approach, the "single-storm" method, assumes that the recurrence interval of a given rain event produces a flood with the same recurrence interval (e.g., that the 2-year storm produces the 2-year streamflow event). By modeling several design storms across a range of recurrence intervals, the flood flow recurrence intervals can be estimated. A second approach, the "continuous" method, uses a long record of precipitation, either measured at a nearby station or synthesized, and models the flood flows that would have occurred during this time period. These models can account for changes in basin characteristics due to previous storms. After simulating a long record, the series of annual peak floods are then analyzed for flow frequency by using techniques such as the Log-Pearson Type III analysis described earlier.

This study focuses on single-storm rainfall-runoff modeling in small watersheds and tests how applicable it is to OHWM delineations. Each model and modeling approach has advantages and disadvantages. For medium and large watershed models and for the continuous modeling methods, the simulations can be more complicated, difficult to run, and more challenging to review than models of small watersheds. The added complications 
do not necessarily improve the predictions of recurrence intervals. For medium and large watersheds, regression equation and gage analysis are typically the preferred flow frequency analysis because they are more straightforward and still produce defensible results for OHWM purposes.

\subsection{Testing the rainfall-runoff assumption}

An important limitation in the single-storm approach is the assumption that rainfall of a given recurrence interval produces a flood of the same recurrence interval. Commonly, there is a roughly 1:1 trend between the frequencies of a precipitation event and the associated flood event; but this relationship is not perfect for many reasons, including

- variable precipitation across the watershed;

- antecedent moisture;

- storm duration versus watershed size; and

- other drivers or controls on flood flows, such as snowmelt or dams.

To elaborate, first, precipitation is seldom uniform across an entire watershed, especially as watershed size increases. One portion of a watershed may be experiencing a 5-year, 1-hour precipitation event, but another portion could experience a wholly different event.

Second, the antecedent moisture in a watershed from prior rain events can greatly affect the runoff amount. Moist soil has different infiltration rates and connectivity to groundwater than dry soil (Rawls et al. 1996; Renshaw et al. 2003). If there are two or more rain events in close succession, the early storms make it more likely that the following storms will lead to large floods because the soil is already moist. Antecedent moisture has diminished importance in urbanized watersheds because the infiltration rates are always high in impervious areas regardless of prior rain events.

Third, the duration of the storm versus the size of the watershed can be an important factor in the runoff amount. For example, a 5-year storm of 1hour duration will have a greater effect on peak flow in a 1-square-mile watershed than in a 100-square-mile watershed. In the smaller watershed, 1 hour may be plenty of time to reach peak flow. In the larger watershed, it might take many hours to reach peak flow, at which point the 1-hour storm has already passed. 
Fourth, there may be drivers on flood flows other than precipitation. Snowmelt or rain-on-snow events can cause larger floods than a simple rain event. Also, dam retention, diversions, and other flow manipulations may result in smaller floods than expected for a rain event.

Figure 6 illustrates the point that there is an approximate, but certainly not exact, 1:1 relationship between precipitation recurrence intervals and flow recurrence intervals. The flow recurrence intervals were determined using a Log-Pearson Type III analysis of the peak annual flows at the Mink Brook, Hanover, NH, stream gage maintained formerly by the USGS (\#01141800) and currently by Dartmouth College. Precipitation recurrence intervals were determined for each annual peak flow by using an Extreme Value Type I analysis of precipitation measured in this watershed at the Shattuck observatory, maintained by Dartmouth College. Only daily precipitation totals are available. Because the precipitation events often span two calendar days, the precipitation amounts used in the analysis are the sum of the rainfall on the day of the peak discharge plus the previous day. This relationship is tightest in the vicinity of the moderate to high precipitation events. For some of the smaller storms, there is high scatter in the resulting discharge, in part because snowmelt can cause annual peak flows on warm days with little to no precipitation. High flows with a likely snowmelt component are circled. For these events, the amount of precipitation is not a reliable predictor of the amount of flow.

Figure 6. Recurrence intervals of precipitation and peak annual discharge at Mink Brook, Hanover, NH.

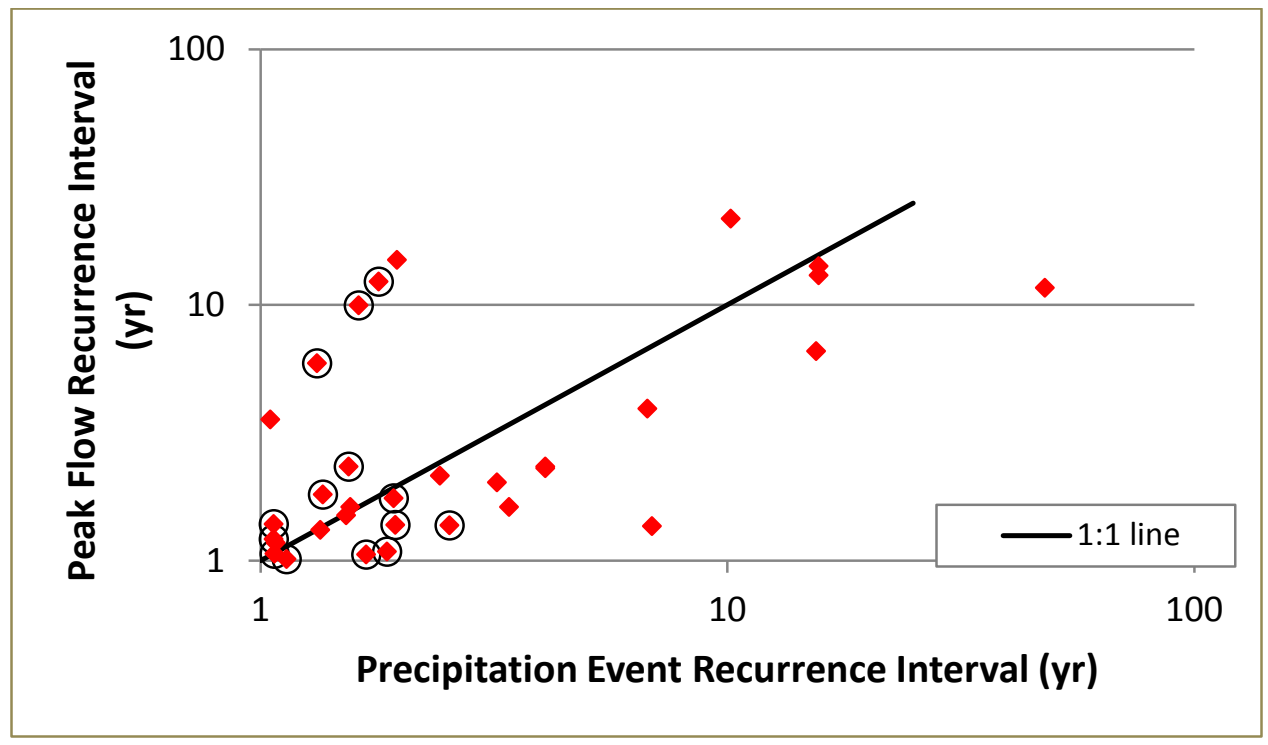


From the scatter in these data and the lack of a clear 1:1 relationship, it is evident that flow frequencies derived from rainfall-runoff modeling cannot be used to definitively determine OHWM.

This scatter in the relationship between rainfall and runoff is also evident in drier landscapes. Returning to Lytle Creek near Fontana, CA, Figure 7 shows the total rainfall over a 48-hour period for each of the peak annual flows measured at the USGS gage. Rainfall was recorded in Fontana and accessed through the Global Historical Climatology Network (National Climatic Data Center 2014). As with the Mink Brook data, only daily total precipitation is available at this site, and precipitation events often span two calendar dates. Thus, the precipitation amounts used in the analysis are the sum of the rainfall on the day of the peak discharge plus the previous day. These data show the actual values rather than converting them to recurrence intervals to avoid any assumptions in the frequency analyses. Similar to the Mink Brook data, there is not a clear, singular relationship between rainfall and runoff. For example, a storm that produces about 4 in. of rain can result in peak flows ranging from approximately 100 to $9000 \mathrm{ft}^{3} / \mathrm{s}$ in Lytle Creek.

Figure 7. Rainfall-runoff relationship at Lytle Creek near Fontana, CA.

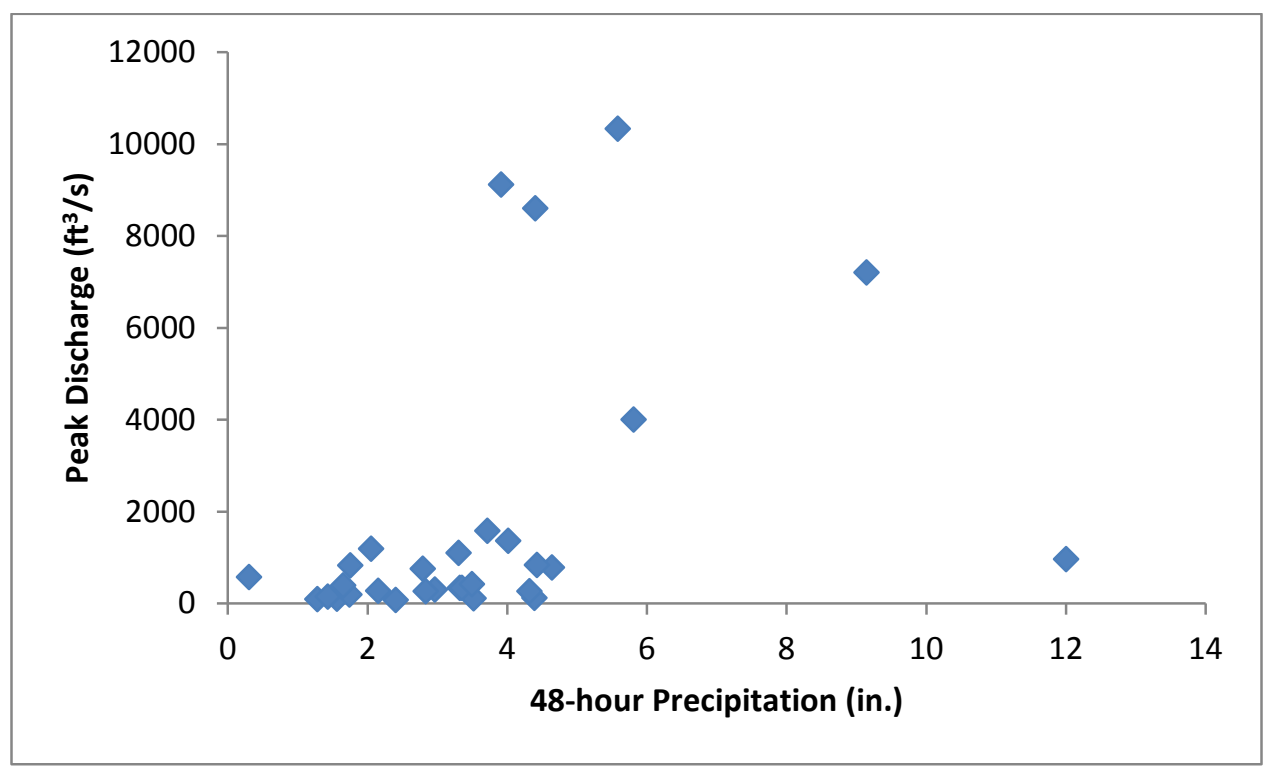

The issues with the variable rainfall-runoff relationship can be reduced by continuous modeling as opposed to the single-storm approach. In continuous modeling, many storm events are simulated over several years by using an actual or synthetic rainfall record. This type of hydrologic modeling can simulate changes in soil moisture; and by accounting for antecedent 
moisture, the model includes some of the variables in the rainfall-runoff relationship.

In some cases, continuous modeling may be preferable over the singlestorm approach; but continuous modeling also has limitations, primarily that it is more complicated and costly. If the hydrologic model simulates soil moisture changes over time when computing runoff, the issues with antecedent moisture can be reduced. Yet other difficulties arise in the soil moisture accounting over time.

Indeed, a general truth about modeling is that many of the assumptions of simple models can be reduced by using more complicated models. However, reducing the number of assumptions and adding complexity to the model does not necessarily reduce uncertainty in the flow frequency simulations. Furthermore, added complexity adds costs and makes models harder to understand and to review. Here, a more complicated model is not necessarily a better model.

\subsection{Testing the Rational Method}

This sections tests the performance of the Rational Method in predicting flow recurrence intervals because the Rational Method is a preferred, relatively simple, and widely used model for small watersheds and because it illustrates how simplifications and assumptions can limit a model's applicability. Several textbooks, online tutorials, and county hydrology manuals show how to use the Rational Method in detail. For example, the Hydrology Manual produced by the Los Angeles County Department of Public Works (2006) provides thorough documentation. Rather than reproduce these comprehensive instructions, below is an overview of the method.

The Rational Method is an empirical model that computes a peak discharge for a small watershed (typically less than 200 acres). It does not produce flow hydrographs (simulating how flow changes over time) nor can it be used to route storm water through a stream network. It simply computes the peak discharge for a given rain event in a given watershed by using the following equation:

$$
Q=C I A,
$$


where

$\mathrm{Q}=$ the peak discharge in units of volume of flow per time,

$\mathrm{C}=$ the runoff coefficient (non-dimensional),

$\mathrm{I}=$ the intensity of rainfall in units of length per time (e.g., inches/ hour), and

$\mathrm{A}=$ the watershed area.

The runoff coefficient is a metric of how much of the rainfall will run off versus how much will infiltrate or otherwise be lost. Pavement and roofs have higher $\mathrm{C}$ values than forest and grassland. In watersheds with several cover types, a composite value for $\mathrm{C}$ can be based on the area-weighted average of each cover type.

The Rational Method simplifies several aspects of a watershed's hydrology, yet it produces valid results in certain applications. The underlying concept is that, in a rain event, some precipitation is runoff and some is lost to infiltration, interception, depression storage, and evaporation. At the outlet of the small watershed, runoff will increase until a time when all points within the watershed are contributing flow. This amount of time is $\mathrm{T}_{\mathrm{c} .} \mathrm{A}$ storm must maintain the given intensity for at least as long as the time of concentration. There are several ways to compute $T_{C}$, which are outlined in hydrology textbooks and manuals (e.g., Maidment 1993).

These simplifications and assumptions make the model easy to use but limit its applications. The invariance of $\mathrm{C}$ and I does not allow infiltration rates or rainfall intensity rates to change over time. However, it is well known that these change over the course of a storm; and antecedent soil moisture from previous storms can affect infiltration greatly. Typical listings for $\mathrm{C}$ in manuals and elsewhere do not account for antecedent moisture. In addition, the Rational Method does not work for large watersheds, where the flood routing and travel times of storm water are important. For example, in a large watershed, the runoff from distant locations may take longer than the storm duration to reach the point of interest; and the peak flow may occur hours after the rain has abated.

In this test of the Rational Method, the study investigates a 140-acre subbasin along Sheep Creek, a small tributary of Lytle Creek near Fontana, $\mathrm{CA}$, and compares results from the Rational Method, StreamStats, and the gage analysis. The subbasin outlet is located at latitude 34.2676, longitude 
-117.4989. This subbasin has a mixture of shrub, grass, and a dirt road for land cover (no urbanization); high runoff soils (hydrologic group D); and steep slopes (averaging 20\%). This physiography yields a characteristic C value of about 0.4 , and $C$ could range from a low estimate of 0.34 to a high estimate of 0.05 (Maidment 1993). The range exists because different sources report different $\mathrm{C}$ values for a given physiography, and some tables show a range of $C$ values. The time of concentration, $T_{c}$, is calculated as about 30 minutes; thus the calculations use the precipitation intensities, I, for the 30-minute duration storms of varying recurrence intervals. The precipitation intensities also have a range of possible values, for example, the 2-year, 30-minute rainfall intensity of 1.02, with a low estimate of 0.85 and a high estimate of 1.25 (NOAA 2014). Table 3 shows the inputs and results of the Rational Method computations at this site and compares the results with the flow recurrence intervals determined from StreamStats and a nearby USGS gage; values are shown with the range of low to high estimates for the inputs and the results.

Table 3. Rational Method inputs and results for Sheep Creek subbasin near Fontana, CA.

\begin{tabular}{|c|c|c|c|c|c|c|c|c|c|c|c|c|c|c|}
\hline \multirow{2}{*}{$\begin{array}{c}\text { Recurrence } \\
\text { Interval }\end{array}$} & \multicolumn{3}{|c|}{$c$} & \multicolumn{3}{|c|}{$\begin{array}{c}/ \\
\text { (in./hr) }\end{array}$} & \multirow{2}{*}{$\begin{array}{c}\begin{array}{c}A \\
\text { (acres) }\end{array} \\
\text { value }\end{array}$} & \multicolumn{3}{|c|}{$\begin{array}{l}\text { Rational Method } \\
\text { Peak Runoff } \\
\left(\mathrm{ft}^{3} / \mathrm{s}\right)\end{array}$} & \multirow{2}{*}{\begin{tabular}{|c}
$\begin{array}{c}\text { Stream- } \\
\text { Stats } \\
\left(\mathrm{ft}^{3} / \mathrm{s}\right)\end{array}$ \\
value
\end{tabular}} & \multicolumn{3}{|c|}{$\begin{array}{c}\text { Gage, Prorated } \\
\left(\mathrm{ft}^{3} / \mathrm{s}\right)\end{array}$} \\
\hline & value & low & high & value & low & high & & value & low & high & & value & low & high \\
\hline 2-year & 0.4 & 0.35 & 0.5 & 1.02 & 0.85 & 1.25 & 140 & 57 & 42 & 88 & 16 & 2 & 2 & 3 \\
\hline 5-year & 0.4 & 0.35 & 0.5 & 1.37 & 1.13 & 1.67 & 140 & 77 & 55 & 117 & 46 & 9 & 7 & 11 \\
\hline 10-year & 0.4 & 0.35 & 0.5 & 1.66 & 1.36 & 2.04 & 140 & 93 & 67 & 143 & 75 & 18 & 14 & 25 \\
\hline 25-year & 0.4 & 0.35 & 0.5 & 2.06 & 1.63 & 2.63 & 140 & 115 & 80 & 184 & 118 & 40 & 29 & 58 \\
\hline 50-year & 0.4 & 0.35 & 0.5 & 2.38 & 1.85 & 3.10 & 140 & 133 & 91 & 217 & 154 & 68 & 47 & 105 \\
\hline 100-year & 0.4 & 0.35 & 0.5 & 2.72 & 2.06 & 3.63 & 140 & 152 & 101 & 254 & 190 & 111 & 74 & 181 \\
\hline
\end{tabular}

There is no set method for determining the uncertainty of the Rational Method results at this location, such as calculating the $90 \%$ confidence intervals or the standard deviation of the hydrologic modeling results. Ground truthing is also not feasible in the absence of long-term gaging records. Recent research has proposed techniques for confidence limits of rainfall-runoff models, but that research is limited to more complicated continuous storm modeling (e.g., J ones and Kay 2007). In the Sheep Creek test watershed, the high estimate is based on the highest reasonable value of $\mathrm{C}(0.5)$ and the upper limit of the published rainfall intensities (NOAA 2014). The low estimate is based on the lowest reasonable value of $\mathrm{C}(0.35)$ and the lower limit of published rainfall intensities. 
Table 3 also compares the estimates for flood recurrence intervals by using the Rational Method, StreamStats, and a prorated gage analysis. The StreamStats regression estimates were derived by first obtaining the watershed characteristics from the StreamStats program and then entering these values into updated regression equations (Gotvald et al. 2012). The prorated gage analysis values for the Sheep Creek subbasin use a LogPearson Type III analysis of the downstream Lytle Creek gage (USGS \#11062000). The Lytle Creek values are prorated by the watershed-area ratio of Lytle Creek (46.3 square miles) to the Sheep Creek site (140 acres).

As illustrated in Figure 8, the methods do not agree exactly. There is uncertainty in each method, and no method can be considered the trutheach is an estimate, some better than others. However, there is general agreement between the Rational Method and StreamStats in the range greater than about 5-year recurrence-interval flows. Furthermore, the subbasin characteristics are within the suggested range for the StreamStats regression equations, giving credence to the StreamStats estimates.

Figure 8. Comparison of the Rational Method with StreamStats and a prorated gage analysis at Sheep Creek near Fontana, CA.

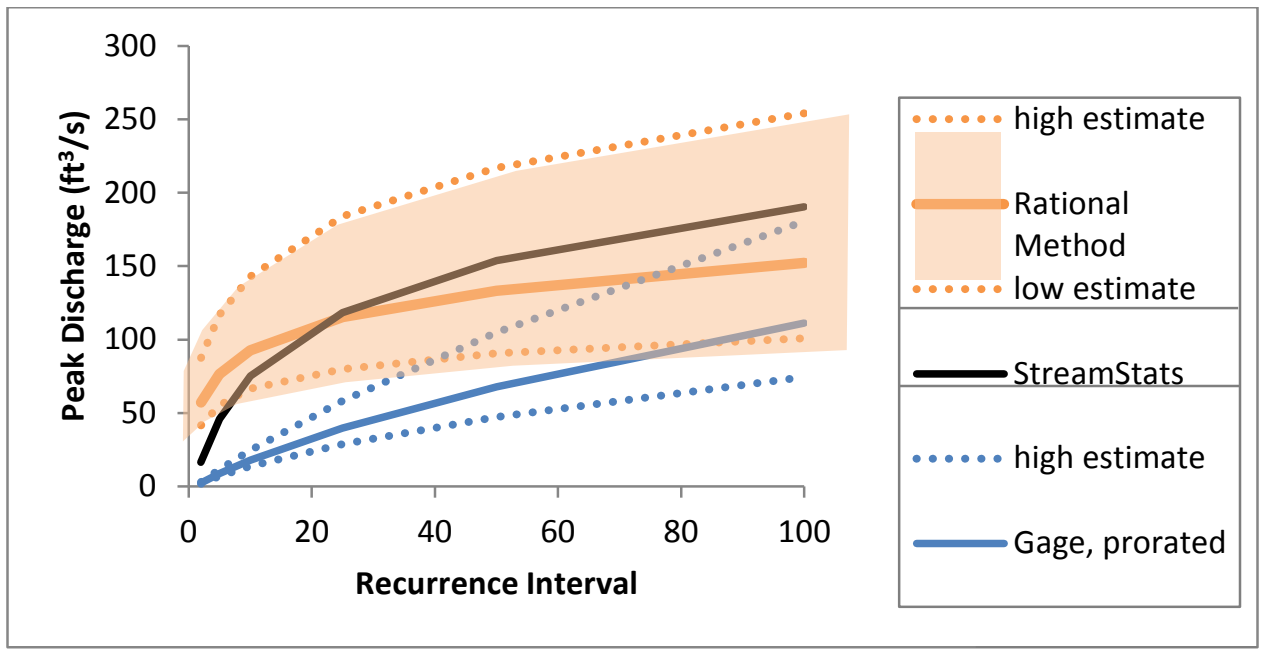

There is little confidence in extrapolating the gage analysis to the smaller Sheep Creek subbasin instills. Even though Sheep Creek is a tributary only 5 miles from the gage, the gaged watershed is much larger, extending 14 miles up to the San Bernardino Mountains. The larger watershed exhibits different composite characteristics; and different hydrologic processes come into play, such as channel storage and network routing. 
Despite the uncertainty and complications of the Rational Method and other rainfall-runoff models, one benefit of rainfall-runoff modeling over gage analysis and regression equations is that the rainfall-runoff models can be adjusted to account for changes in the watershed, such as urbanization or wildfire. Using the Rational Method, one could adjust the $C$ value to account for these changes. Nevertheless, ground truthing and determining uncertainty in these adjusted models would be difficult if not functionally impossible.

\subsection{Pertinence to OHWM}

Rainfall-runoff models are seldom applicable for finding recurrence intervals for OWHM purposes. Typically it is easier, faster, and still defensible to use regression equations, such as those in StreamStats and others for urbanized areas (Sauer et al. 1983). Rainfall-runoff models may be applicable to OHWM delineation when regression equations and gage analysis are not applicable to a site, perhaps because the contributing area is very small, highly manipulated, or lacking nearby gages. In these cases, simple rainfall-runoff models are likely the preferred option with the recognition that uncertainty may be high. Given that recurrence intervals are supplemental information to the primary field indicators in OHWM delineation, the costs of more complicated rainfall-runoff models generally outweigh the benefits. 


\section{Applicability of Modeling Flow Frequency for OHWM Delineation}

As shown throughout this document, there are multiple methods of flow frequency analysis, each with different benefits and limitations. In most cases, regional regression equations are the first choice for estimating flood recurrence intervals for OHWM purposes. They are easy to use and provide defensible results in many settings. In locations near a gage, regression equations can be combined with gage analysis (Blakemore et al. 1994) to provide more-reliable estimates of flood flow frequencies. There are many locations where regression equations are not applicable and gage records are not available. These are generally highly manipulated watersheds or very small watersheds that are outside the valid range of watershed characteristics for the regression equations. For small and moderatesized watersheds, rainfall-runoff models, such as the Rational Method, SCS method, or other rainfall-runoff models, may be applicable. In these cases and especially in large watersheds where more complicated, laborintensive models are required, the benefits of the models must be weighed against the costs.

Throughout this document it is clear that all of the models-gage analysis relationships, regression equations, and rainfall-runoff models-have uncertainty that limits their applicability to OHWM delineation. If one were to model the water surface elevation and lateral extent of streamflow for a specific recurrence interval, then that estimate might have a substantial window of error associated with it. This error is compounded by the errors in the hydraulic model used to determine the water surface elevation and lateral extent for the modeled discharge. Thus, the OHWM should typically not be precisely delineated based on a modeled streamflow recurrence interval (Figure 9A).

However, this is not to say that streamflow statistics have no utility for OHWM delineation purposes. For example, one could model the amount of streamflow required to inundate a stream channel to a particular point (e.g., to the elevation of a surveyed field feature) and then estimate the range of recurrence intervals associated with this flow (Figure 9B). If the range of recurrence interval is far beyond the bounds of what could reasonably be associated with the OHWM, then this information could potentially rule out misleading field indicators. In short, this information can 
add context to the physical features observed in the field; and this can help to narrow down the OHWM location.

Figure 9. Different applications of OHWM in modeling: (A) invalid and (B) sometimes appropriate.

A.

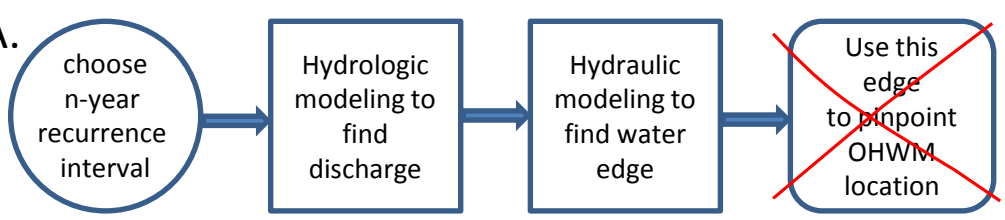

B.

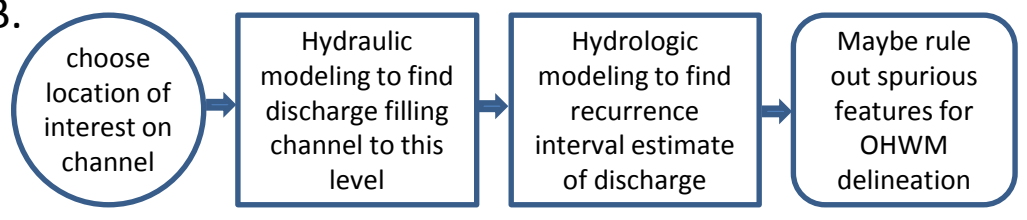

The use of hydrologic modeling for OHWM delineation purposes should be undertaken with full consideration of the associated limitations. All model results have uncertainty, even if that uncertainty is not reported. Though the hydrologic models investigated here can be fraught with difficulty and uncertainty, information from modeling is often better than no information at all. Hydrologic modeling is typically best used to provide supplemental information to combine with field evidence. 


\section{Summary}

This document focuses on the methods and limitations of determining flood recurrence intervals through modeling and the applicability of such methods for OHWM delineation purposes. Companion documents focus on the use of hydraulic modeling for OHWM delineation (Gartner et al. 2016a) and an investigation of combining the use of hydraulic modeling, hydrologic modeling, and field evidence for OHWM delineation (Gartner et al. 2016b).

This report investigated and tested three modeling approaches to flood frequency analysis that could be useful in OHWM delineation. The principal conclusions are that (1) there are multiple ways to estimate streamflow recurrence intervals, each with its own benefits and limitations and each giving slightly different results; (2) the uncertainty in flow frequency analysis is one of several reasons why the OHWM typically should not be delineated based on the inundation extent of a specific flow recurrence interval; and (3) despite this uncertainty, flow frequency analysis can assist in OHWM delineation by bringing quantitative analysis to help eliminate or support potential OHWM locations observed in the field. 


\section{References}

Baer, E. M. 2014. Teaching recurrence intervals. http://serc.carleton.edu/quantskills/methods/quantlit/RInt.html (accessed J uly 2014).

Blakemore, E. T., H. W. Hjalmarson, and S. D. Waltemeyer. 1994. Methods for Estimating Magnitude and Frequency of Floods in the Southwestern United States. Water-Supply Paper 2433. Reston, VA: U.S. Geological Survey.

Curtis, K. E., R. L. Lichvar, and L. E. Dixon. 2011. Ordinary High Flows and the StageDischarge Relationship in the Arid West Region. ERDC/CRREL TR-11-12. Hanover, NH: U.S. Army Engineer Research and Development Center.

Feldman, A. D. 1979. Flood Hydrograph and Peak Flow Frequency Analysis. TP-62. Davis, CA: U.S. Army Corps of Engineers Hydrologic Engineering Center.

Gartner, J . D., M. K. Mersel, L. E. Lefebvre, and R. W. Lichvar. 2016a. The Benefits and Limitations of Hydraulic Modeling for Ordinary High Water Mark Delineation. ERDC/ CRREL TR-16-1. Hanover, NH: U.S. Army Engineer Research and Development Center.

Gartner, J . D., R. W. Lichvar, M. K. Mersel, and L. E. Lefebvre. 2016b. Integrating Hydrologic Modeling, Hydraulic Modeling, and Field Data for Ordinary High Water Mark Delineation. ERDC/ CRREL TR-16-3. Hanover, NH: U.S. Army Engineer Research and Development Center.

Gotvald, A. J ., N. A. Barth, A. G. Veilleux, and C. Parrett. 2012. Methods for Determining Magnitude and Frequency of Floods in California, Based on Data Through Water Year 2006. Scientific Investigations Report 2012- 5113. Reston, VA: U.S. Geological Survey.

Hirsch, R. M., and J . E. Costa. 2004. U.S. Stream Flow Measurement and Data Dissemination Improve. EOS, Transactions American Geophysical Union 85 (21): 197-203.

IACWD (Interagency Advisory Committee on Water Data). 1982. Guidelines for Determining Flood Flow Frequency. Bulletin 17B of the Hydrology Subcommittee. Reston, VA: U.S. Geological Survey, Office of Water Data Coordination.

J ones, D. A., and A. L. Kay. 2007. Uncertainty Analysis for Estimating Flood Frequencies for Ungauged Catchments Using Rainfall-Runoff Models. Advances in Water Resources 30 (5): 1190- 1204.

Kirby, W. H., and M. E. Moss. 1987. Summary of Flood-Frequency Analysis in the United States. J ournal of Hydrology 96 (1): 5- 14.

Knighton, D. 1998. Fluvial Forms and Processes: A New Perspective. New York: Routledge. 
Lanfear, K. J ., and R. M. Hirsch. 1999. USGS Study Reveals a Decline in Long-Record Streamgages. EOS, Transactions American Geophysical Union 80 (50): 605607.

Lichvar, R. W., and S. McColley. 2008. A Field Guide to the Identification of the Ordinary High Water Mark (OHWM) in the Arid West Region of the Western United States: A Delineation Manual. ERDC/CRREL TR-08-12. Hanover, NH: U.S. Army Engineer Research and Development Center.

Lichvar, R., D. Finnegan, M. Ericsson, and W. Ochs. 2006. Distribution of Ordinary High Water Mark (OHWM) Indicators and Their Reliability in Identifying the Limits of "Waters of the United States" in Arid Southwestern Channels. ERDC/ CRREL TR-06-o5. Hanover, NH: U.S. Army Engineer Research and Development Center.

Los Angeles County Department of Public Works. 2006. Hydrology Manual. Los Angeles, CA: Los Angeles County Department of Public Works, Water Resources Division.

Maidment, D. R. 1993. Handbook of Hydrology. New York: McGraw-Hill.

Mersel, M. K., and R. W. Lichvar. 2014. A Guide to Ordinary High Water Mark (OHWM) Delineation for Non-Perennial Streams in the Western Mountains, Valleys, and Coast Region of the United States. ERDC/ CRREL TR-14-13. Hanover, NH: U.S. Army Engineer Research and Development Center.

Milly, P. C. D., J . Betancourt, M. Falkenmark, R. M. Hirsch, Z. W. Kundzewicz, D. P. Lettenmaier, and R. H. Stouffer. 2008. Stationarity is Dead: Whither Water Management? Science 319:573- 574.

National Climatic Data Center. 2014. Global Historical Climatology Network V2. http://www.ncdc.noaa.gov/oa/climate/ghcn-daily/. (Data obtained using Climate Reanalyzer, http://cci-reanalyzer.org, Climate Change Institute, University of Maine, Orono.)

NOAA (National Oceanic and Atmospheric Administration). 2014. Precipitation Frequency Data Server. http://dipper.nws.noaa.gov/hdsc/pfds/ (accessed 2 J uly 2014).

Ponce, V. M. 1989. Engineering Hydrology: Principles and Practices. Englewood Cliffs, NJ : Prentice Hall.

Rantz, S. E. 1982. Measurement and Computation of Streamflow. 2 vols. Water-Supply Paper 2175. Reston, VA: U.S. Geological Survey.

Rawls, W. J., G. David, J . A. Mullen, and T. J. Ward. 1996. Hydrology Handbook. 2nd ed. Manuals and Reports on Engineering Practice No. 28. Reston, VA: American Society of Civil Engineers.

Renshaw, C. E., X. Feng, K. J. Sinclair, and R. H. Dums. 2003. The Use of Stream Flow Routing for Direct Channel Precipitation with Isotopically-Based Hydrograph Separations: The Role of New Water in Stormflow Generation. J ournal of Hydrology 273 (1): 205- 216. 
Ries, K. G., III 2007. The National Streamflow Statistics Program: A Computer Program for Estimating Streamflow Statistics for Ungaged Sites. U.S. Geological Survey Techniques and Methods 4-A6. Reston, VA: U.S. Geological Survey.

Ries, K. G., J . D. Guthrie, A. H. Rea, P. A. Steeves, and D. W. Stewart. 2008. StreamStats: A Water Resources Web Application. Reston, VA: U.S. Geological Survey.

Sauer, V. B., W. O. Thomas, Jr., V. A. Stricker, and K. V. Wilson. 1983. Flood Characteristics of Urban Watersheds in the United States. Water-Supply Paper 2207. Reston, VA: U.S. Geological Survey.

Scharffenberg, W. A. 2013. Hydrologic modeling system HEC-HMS user's manual 4.0. Davis, CA: U.S. Army Corps of Engineers, Hydrologic Engineering Center.

Turnipseed, D. P., and V. B. Sauer. 2010. Discharge Measurements at Gaging Stations. Geological Survey Techniques and Methods 3-A8. Reston, VA: U.S. Geological Survey.

USGS (U.S. Geological Survey). 2014. Number of USGS Streamgages Through Time. USGS National Streamflow Information Program. http://water.usgs.gov/nsip/history1.html (accessed J uly 2014).

Williams, G. P. 1978. Bank-Full Discharge of Rivers. Water Resources Research 14 (6): 1141- 1154 . 


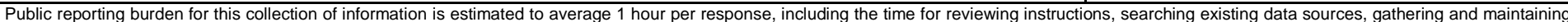

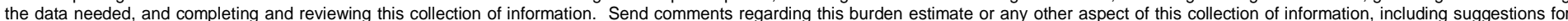

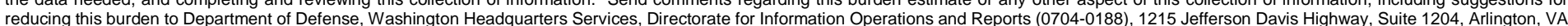

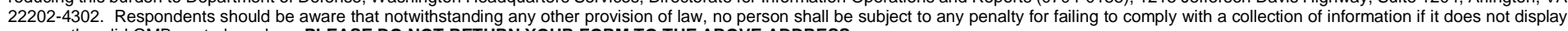
a currently valid OMB control number. PLEASE DO NOT RETURN YOUR FORM TO THE ABOVE ADDRESS.
1. REPORT DATE (DD-MM-YYYY)
2. REPORT TYPE
February 2016
Technical Report/Final

3. DATES COVERED (From - To)

\section{TITLE AND SUBTITLE}

Hydrologic Modeling and Flood Frequency Analysis for Ordinary High Water

Mark Delineation

5a. CONTRACT NUMBER

5b. GRANT NUMBER

5c. PROGRAM ELEMENT NUMBER

\section{AUTHOR(S)}

5d. PROJECT NUMBER

John D. Gartner, Mathew K. Mersel, and Robert W. Lichvar

5e. TASK NUMBER

5f. WORK UNIT NUMBER

\section{PERFORMING ORGANIZATION NAME(S) AND ADDRESS(ES)}

U.S. Army Engineer Research and Development Center (ERDC)

Cold Regions Research and Engineering Laboratory (CRREL)

8. PERFORMING ORGANIZATION REPORT NUMBER

72 Lyme Road

Hanover, NH 03755-1290

9. SPONSORING I MONITORING AGENCY NAME(S) AND ADDRESS(ES)

Headquarters, U.S. Army Corps of Engineers

Washington, DC 20314-1000

ERDC/CRREL TR-16-2

\section{DISTRIBUTION I AVAILABILITY STATEMENT}

Approved for public release; distribution is unlimited.

\section{SUPPLEMENTARY NOTES}

Wetlands Regulatory Assistance Program (WRAP)

\section{ABSTRACT}

This document explores hydrologic modeling and flood frequency analysis for ordinary high water mark (OHWM) delineation performed for Clean Water Act implementation and other applications. OHWM delineation in streams and rivers is primarily based on field indicators, and the streamflow recurrence interval corresponding with the OHWM varies between different sites. However, recurrence intervals are the primary metric that hydrologists use to characterize the variability of streamflow, and recurrence intervals provide context for understanding the OHWM. This document tests modeling techniques for estimating flow frequency and assesses their utility for OHWM delineation. The principal conclusions are that (1) there are multiple ways to estimate streamflow recurrence intervals, each having benefits, limitations, and slightly different results; (2) the uncertainty in flow frequency analysis is one reason why the OHWM typically should not be delineated based on the inundation extent of a specific flow recurrence interval; and (3) despite this uncertainty, quantitative flow frequency analysis can assist in OHWM delineation by helping to eliminate or support potential OHWM locations observed in the field. Two separate companion documents focus on (a) hydraulic modeling for OHWM delineation and (b) the combined use of hydraulic modeling, flow frequency analysis, and field evidence for OHWM delineation.

\begin{tabular}{|ll|}
\hline 15. SUBJECT TERMS & Hydraulic models \\
Delineation & Hydrologic models \\
Fluvial Geomorphology & OHWM \\
\hline
\end{tabular}

16. SECURITY CLASSIFICATION OF:

\begin{tabular}{|l|r|}
\hline $\begin{array}{c}\text { a. REPORT } \\
\text { Unclassified }\end{array}$ & $\begin{array}{r}\text { b. ABSTRACT } \\
\text { Unclassified }\end{array}$ \\
\hline
\end{tabular}

\section{c. THIS PAGE}

Unclassified
Ordinary high water mark

Riparian Vegetation

WRAP

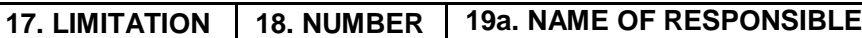 OF ABSTRACT OF PAGES PERSON}

SAR
50 19b. TELEPHONE NUMBER (include area code) 